\title{
EL MUCHACHO DESNUDO DEL PRENDIMIENTO DE MARCOS (14, 51-52): UNA NUEVA INTERPRETACIÓN ${ }^{1}$
}

\section{THE NAKED YOUNG MAN IN THE SCENE OF JESUS’ ARREST (MK 14, 51-52). A NEW INTERPRETATION}

\author{
Gonzalo Fontana Elboj \\ Universidad de Zaragoza \\ gonzalfontana@gmail.com
}

DOI: $10.1387 /$ veleia.16833

\begin{abstract}
Resumen: El objetivo del presente trabajo es el de ofrecer una nueva interpretación a uno de los más enigmáticos personajes del Nuevo Testamento: el misterioso joven que huye desnudo en la escena del prendimiento $(M c$ 14, 51-52). Las propuestas de la Antigüedad trataron de identificarlo con diversas figuras históricas (Santiago, el hermano del Seńor; el apóstol Juan...). Eruditos posteriores consideraron que era una alegoría del bautismo cristiano. En contraste, según nuestra hipótesis, el personaje es una creación alegórica de la tradición oral más antigua del cristianismo. De naturaleza simbólica y no histórica, reflejaba la realidad crística de Jesús: Cristo iba a escapar a la muerte y sus captores se quedaron con un simple cuerpo, cuya imagen era la mortaja que cubría el cuerpo desnudo del joven. Así, Cristo - y no Jesús - quedó preservado de la muerte y a la espera de su resurrección. Tras la muerte y sepultura de Jesús, ese mismo joven se manifiesta revestido de una resplandeciente túnica que expresa la plenitud de su glorificación mesiánica (cf. $M c$ 16, 2-6). Tiempo después, cuando la narración teológica se puso por escrito, el autor de Marcos lo transformó en un joven ángel.
\end{abstract}

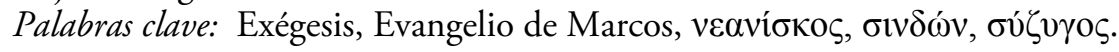

Abstract: The purpose of this paper is to offer a new interpretation of one of the most enigmatic figures of the New Testament, the mysterious young man who flees naked at the scene of Jesus' arrest (Mk 14, 51-52). Traditionally, this character has been identified with different historical figures (James, Lord's brother, the apostle John, etc.). Other scholars considered this episode an allegory of Christian baptism. In contrast, according to our hypothesis, this character is an allegorical creation by the earliest Christian oral tradition: this figure, which had no historical but symbolic nature, reflected the immortal christic reality of Jesus. In other words, Christ would escape death. His captors caught a mere body,

${ }^{1}$ El presente trabajo ha sido realizado en el marco del Proyecto HAR2014a-57067-P («Procesos de aculturación religiosa en el Mundo Antiguo y la América colonial») financiado por el Ministerio de Ciencia e Innovación. Investigador Principal: Dr. Francisco Marco Simón, Catedrático de Historia Antigua de la Univer- sidad de Zaragoza. Por otra parte, desde estas líneas quiero expresar mi gratitud a los dos evaluadores que juzgaron mi original por el conjunto de sus atinadas críticas y sugerencias. Su anónima labor ha contribuido a mejorar sustancialmente el artículo. 
whose image was the shroud that covered the naked body of this young man. Therefore, Christ —and not Jesus - was preserved from death and he awaited his resurrection. After Jesus' death and burial, the above referred young man appears dressed in a bright robe that indicates his full messianic glorification (cf. $M k 16,2-6$ ). Later on, when the theological narrative was written down, the author of the Gospel of Mark transformed him into a young angel.

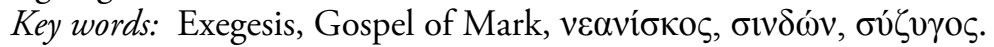

Recibido: 20-07-2015 Informado: 08-11-2015 Definitivo: 04-12-2015

\section{Planteamiento de la Cuestión}

El propósito del presente trabajo no es sino el de ofrecer una nueva interpretación a una de las figuras más enigmáticas del Nuevo Testamento: el misterioso muchacho que huye desnudo en la escena del prendimiento marcano, individuo que, por otra parte, carece de paralelo en el resto de los evangelios: ${ }^{2}$

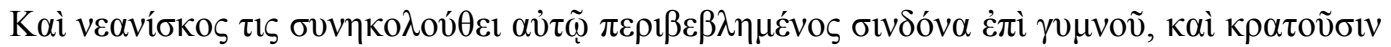

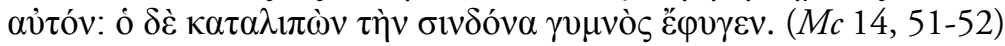

Un joven le seguía cubierto solo de un lienzo; y le detienen. Pero él, dejando el lienzo, se escapó desnudo. (Trad. Biblia de Jerusalén)

Desconocido, en principio, por las demás narraciones evangélicas, este extraño personaje constituyó un reto para los exégetas, que, ya desde la Antigüedad, trataron de identificarlo con un nombre concreto. Tal es el caso de Epifanio de Salamina, quien quiso dar a entender que se trataba de Santiago, el hermano del Señor:

Se hallaban junto a la cruz María la Magdalena, María la de Cleofás, María (la madre de Rufo), y la otra María, Salomé y otras mujeres. Y no afirmó que 'José estaba alli' o 'Santiago, el hermano del Señor», quien murió virgen a los noventa y seis años. Ningún hierro tocó su cabeza, jamás acudió a un baño y nunca comió carne. No llevó nunca ropa de repuesto y su vestido era exclusivamente de un raído lino puro'; ${ }^{3}$ tal como dice en el Evangelio: 'El muchacho huyó, y aban-

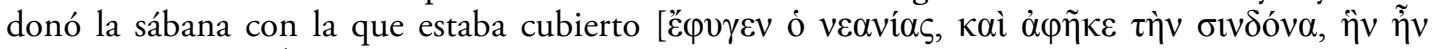
$\pi \varepsilon \rho 1 \beta \varepsilon \beta \lambda \eta \mu \varepsilon ́ v o s]{ }^{4}{ }^{4}$ (Haer. 78, 13, 2-14, 2; trad. G. Fontana) ${ }^{5}$

2 En rigor, de entre los aproximadamente cuarenta personajes citados en el Evangelio de Marcos hay catorce individuos anónimos. Este sería uno de ellos. Un examen de la cuestión, en: http://catholic-resources.org/Bible/Mark-People_Places.htm. (Online).

${ }^{3}$ Evidentemente, la fuente de la que se sirve el heresiólogo es la célebre descripción de Hegesipo (apud Eus. $H E$ II 23, 4-6).

${ }^{4}$ Obsérvese que aquí Epifanio está parafraseando, y no citando literalmente, el texto de Marcos.

\footnotetext{
5 La idea se mantuvo en vigencia durante muchos siglos y así el comentario del bizantino Teofilacto (10551107) sigue ofreciendo semejante identificación del personaje: «Adolescentulus autem quispiam sequebatur. Hic adolescentulus erat quidam e domo in qua comederant pascha. Quidam autem dicunt illum fuisse Iacobum fratrem Domini qui cognominabatur Iustus. Hic enim una veste usus est (...) et hic igitur relicta sindone fugit.» (Theoph. 1527, 125; trad. latina de Ecolampadio). Por otra parte, la idea de que quizás pudiera ser el
} 
Ahora bien, los cálculos le fallaron estrepitosamente al heresiólogo, ya que un personaje muerto en el año 62 ( $c f$. Josefo $A J$ XX 9, 1) a los 96 años habría tenido más de 60 en los años treinta y di-

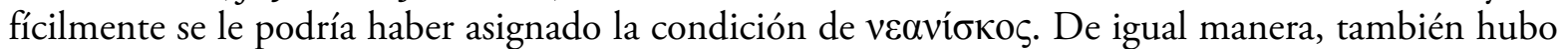
quien lo identificó con el apóstol Juan. Así lo manifiesta un anónimo comentarista griego de la Antigüedad, aunque él mismo acaba por rechazar su propia conjetura. Se trataba de una situación inconcebible en un personaje de tan probada gravedad:

An hic Ioannes erat? (...) non erat verisimile ipsum sola involutum sindone, caetera nudum fuisse. Non enim id convenit ei gravitati, quam Ioannis tam laudati persona requirit. (citamos por la trad. latina de Petrus Possinus 1673, 327) ${ }^{6}$

Ya en época moderna la indagación prosiguió y los escrituristas siguieron tratando de ver en él a otros personajes históricos concretos. A este respecto, baste recordar las hipótesis, ya muy antiguas, que veían en este muchacho a Juan Marcos, supuesto autor del propio Evangelio de Marcos (cf. Papías apud Eus. $H E$ III 39, 15), el cual habría pintado un pequeño retrato de sí mismo en un rincón de su obra. ${ }^{7}$

dueño, o acaso uno de los miembros de la casa en la que se había celebrado la Última Cena, ya había sido apuntada por Víctor de Antioquía (s. v): «Forte hic e domo illa ubi Pascha comederant fuerat: in quo nihil insolitum est.» (apud Possinus 1673, 328).

${ }^{6}$ Ya en nuestros tiempos, Brown $(1994,296)$ también rechaza la identificación del personaje con Juan, idea que remonta a Gregorio Magno: «Stetit etiam Joannes, cui ipso crucis tempore dictum est (...) quia de ipso quoque scriptum est, quod adolescens quidam sequebatur illum amictus sindone super nudo..." (Mor. XIV 57). De hecho, la única causa para aventurar tal idea se basa en la tradición de que Juan era el más joven de los apóstoles: «Sed notandum solertius quod de hoc adolescente scribens evangelista, non ait quia fugit a comitatu, vel fugit a sequendo Dominum, sed, rejecta, inquit, sindone, nudus profugit $a b$ eis. Fugit enim ab hostibus, quorum et praesentiam detestabatur et facta; non fugit a Domino Salvatore ac magistro suo, cujus amorem etiam corpore absens fixum in corde servavit. Neque aliquid vetat intelligi Joannem hunc fuisse adolescentem, dilectum prae caeteris magistro discipulum. Nam et illum eo tempore fuisse adolescentem, longa post haec in carne vita ejus indicio est.» (Beda In Ev. Marc. 4, 43). En consecuencia, la tradición iconográfica tiende a representarlo como un joven imberbe ya desde la Antigüedad Tardía. Sin embargo, no hay ningún indicio en los textos antiguos que avale tal caracterización juvenil.

7 Y en la misma línea, según subraya Dibelius (1949, 106), este vergonzoso episodio jamás habría sido incluido en la narración si el joven no hubiera sido alguien muy cercano al primitivo narrador. La misma idea, en McIndoe (1969, 125). Este Juan Mar- cos es un personaje relativamente bien conocido gracias a las diversas menciones neotestamentarias que aluden a él como acompañante de Pablo, Bernabé y, posteriormente, de Pedro (cf. Fil 24; Col 4, 10; 1Pe 5, 13 ; Hchs 12, 25; 13, 13; 15, 36-41) y es considerado por la tradición como el autor del evangelio que lleva su nombre. La atribución es antigua, ya que remonta a Papías de Hierápolis, quien, a su vez, decía recoger una tradición legada por el misterioso "Juan el Presbítero" (apud Eus. HE III 39, 14). Ahora bien, nos hallamos ante una noticia que hay que tratar con suma cautela. Estas referencias, compuestas acaso a mediados del s. II, son, como ya se ha señalado con anterioridad (Fontana 2013), resultado de un intento especulativo de vincular los textos evangélicos del canon a un conjunto de personajes del cristianismo primitivo, no de auténticas noticias históricas fruto de la indagación en los hechos del pasado cristiano. Así, el relato de $\mathrm{He}_{-}$ chos lo presenta como un auxiliar en la misión de $\mathrm{Pa}$ blo y Bernabé, hasta que, tras una disputa, se queda como compañero exclusivo de Bernabé. La noticia de Colosenses relativa a que era pariente de Bernabé

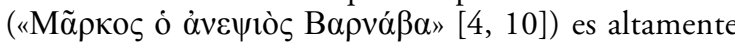
dudosa, pues la carta es un texto tardío que no es obra de Pablo. Y más tardía todavía, ya de muy entrado el s. II, es la mención de la Primera carta de Pedro, en cuyo epílogo aparece residiendo en Babilonia (i. e.

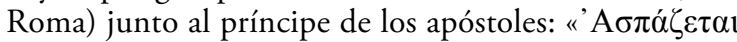

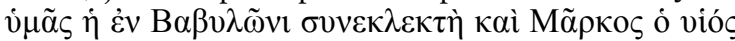
Hov.» (1Pe 5, 13). Aprovechando esta noticia, Papías -o quizás su fuente, Juan el Presbítero- decidió que el texto del más breve de los evangelios hallaría mejor acogida si, con semejante atribución, quedaba blindado de cualquier controversia. 
Por su parte, y ya en tiempos más recientes, Bauckham (2007, 197-198) considera que es un anónimo testigo presencial que se quedó junto a Jesús después de la huida de los discípulos y que garantizaría el relato de lo acaecido en el prendimiento. ${ }^{8}$ Más aún, Theissen $(1999,184-189)$ consideró que este desconocido joven desnudo, así como el anónimo espadachín citado en $M c$ 14, 47, poseen plena consistencia histórica, ya que ese anonimato sería, precisamente, un recurso para proteger a seguidores de Jesús vivos todavía. ${ }^{9}$ De ahí que considere que el relato premarcano de la Pasión es muy antiguo. ${ }^{10}$ También en nuestros días, Haren $(1998,526)$ - lo mismo que Fowler (1998, 3-22) - consideran, en una línea historicista, que el personaje es nada menos que Lázaro. Sin embargo, como ya hemos argumentado recientemente (Fontana 2014a, 108-114), Lázaro no es ningún personaje histórico, sino una ficción literaria urdida por un interpolador que se sirvió de diversos elementos procedentes de Lucas para crear el relato del más famoso de los milagros evangélicos. De ahí que, independientemente de su imposible historicidad, no podemos considerarlo perteneciente a ninguna tradición conocida por Marcos. Lo mismo, aunque por distintas razones, podríamos decir de Santiago y Juan: ¿Por qué no mencionar a Juan, personaje perfectamente conocido por Marcos (p. ej. 1, 16-20; 10, 37)? Y respecto a la identificación con Santiago, solo decir que es más que dudosa; sobre todo, porque su adscripción al movimiento de Jesús es, muy posiblemente, posterior a la resurrección ( $c f .1$ Cor 15,7$) ;{ }^{11}$ y lo que es más, porque el vínculo establecido por Epifanio está francamente traído por los pelos.

8 Una revisión exhaustiva de las posibles identificaciones que se han dado al personaje, en Haren (1998, 525-531). De entre estas, destacamos la fantasiosa caracterización del muchacho que, sin la más mínima base argumental, hace Lohmeyer (1937, ad loc.), pues hace de él un individuo acaudalado. ¿Acaso por ser el supuesto dueño de la casa en la que se celebró la Última Cena? ¿Acaso por llevar una prenda de lino? No son, a nuestro juicio, argumentos convincentes.

9 De hecho, por algún otro pasaje de Marcos, sabemos que el autor menciona a individuos concretos de su propia comunidad que sirven de testigos de la veracidad de los acontecimientos narrados: «Y obligaron a uno que pasaba, a Simón de Cirene, que volvía del campo, el padre de Alejandro y de Rufo, a que llevara su cruz.» (Mc 15, 21).

10 Por otra parte, el personaje también se halla presente en el fragmento 1 del Evangelio secreto de Marcos

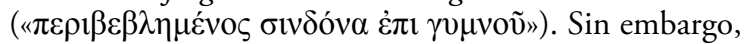
despachamos el eventual problema de que ambos relatos pudieran pertenecer a una tradición común de la manera más obvia y sencilla: en la medida en que el texto del supuesto apócrifo no es sino una desvergonzada falsificación de Smith, no hay nada que discutir respecto al asunto. La bibliografía sobre la cuestión es amplísima. En este punto, nos limitamos a citar las exhaustivas monografías de Brown (2005) y Jeffery (2007). No obstante, cabe señalar que la habilidad de la falsificación engañó a estudiosos tan eminentes como Koester (1983, 35-85) o aquí, en nuestro país, a Rius-Camps (2008, 82-84; 87; 194-195; 328), quien considera que estos fragmentos pertenecían a una versión perdida de Marcos. Nada más lejos de la realidad: los fragmentos ubicados en la supuesta carta de Clemente fotografiada por Smith no son sino un pastiche de multitud de elementos procedentes de los canónicos y adobados con unas pinceladas de aire gnóstico. No es este el ámbito para entrar en detalle sobre la cuestión, pero lo que está claro es que Marcos nunca pudo incluir semejante engendro en ninguna de sus etapas redaccionales. Y lo que es peor, al ser aceptada la impostura de buena fe por muchos otros eruditos, abrió camino para nuevos disparates históricos, que Smith debía de contemplar con suma satisfacción. Ejemplar en tal sentido es el trabajo de Talley (1982, 594-612), quien sostuvo que el «texto iniciático" del Evangelio secreto de Marcos era nada menos que la fuente de la vieja fiesta litúrgica bautismal «de Lázaro», celebrada anualmente por la iglesia de Alejandría, antes del patriarcado de Atanasio.

${ }^{11}$ No hace falta insistir en los testimonios que dan cuenta de los resquemores entre Jesús y su propia familia, conflicto que se materializa en toda su crudeza en el Evangelio de Marcos, en donde se explicita que sus parientes lo tenían por un perturbado: «ह̌̉ $\varepsilon \gamma o v$

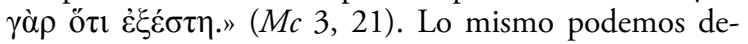

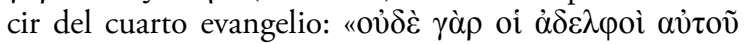

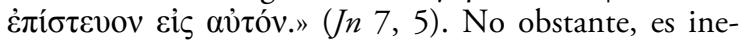
ludible apuntar que esta mención a la increencia de los hermanos de Jesús es, seguramente, una sutil alusión de corte polémico con la que el autor manifestaba su distanciamiento respecto a la comunidad judeo-cristiana, regida precisamente por Santiago, «el hermano del Se- 
Cerramos este repaso de propuestas destinadas a identificar al muchacho con un individuo concreto con la inverosímil hipótesis de Barnes, quien considera que era el dueño del huerto de Getsemaní, en donde se produjo el arresto:

Who this was we have no means of determining, but it seems not improbable that he may have been the owner of the garden, and that he may have had an understanding with Jesus that he should visit it for retirement when he withdrew from the city. That he was not one of the apostles is clear. It is probable that he was roused from sleep by the noise made by the rabble, ${ }^{12}$ and came to render any aid in his power in quelling the disturbance. (Albert Barnes' Notes on the Whole Bible.

En: http://www.studylight.org/commentaries/bnb/view.cgi?bk=40\&ch=14. [Online])

Así pues, estos intentos de identificar al misterioso joven con un personaje concreto resultaban altamente discutibles, por no decir insostenibles. Y más estériles todavía eran las indagaciones destinadas a precisar en términos arqueológicos los detalles del relato. Tal es el caso de quienes trata-

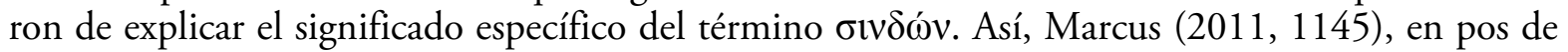
los trabajos previos de Jackson $(1997,279)$, Edwards $(1992,236)$ y Smith $(1973,176)$ dedica una minuciosa atención a la cuestión: "El término sindon podía utilizarse como vestimenta exterior o interior, pero aquí al parecer se refiere a una suerte de suspensorio». Menos preciso, M. Smith, citando a Diógenes Laercio (Vit. 6, 90), se limita a señalar que no era una vestidura apropiada para ser llevada en público. Por su parte, Neirynck (1979, 63-65) dice que el joven no huyó completamente desnudo, sino en ropa interior. ${ }^{13}$ Las hipótesis llegan, a veces, a rozar lo absurdo. Así, Cranfield (1959, ad loc.) consideraba que la camisa de lienzo del muchacho constituía una prenda valiosa, ${ }^{14}$ idea que concuerda con la propuesta de Lohmeyer de que se trataba de un joven rico. A

ñor». En cualquier caso, la nota histórica significativa en este caso estriba en que la secuencia de acontecimientos más verosímil nos conduce a pensar que sus parientes, los $\delta \varepsilon \sigma \pi$ óovvor ( $c f$. Gal 1, 19), se sumaron al movimiento cristiano tras su aceptación de las visiones galileas iniciadas por Pedro (cf. 1Cor 15, 7). Tras ello, ya encontramos a Santiago en Jerusalén ( $G a l$ 1, 19), aunque sin llegar a participar del grupo de «los Doce».

12 Aquí Barnes sigue la reconstrucción de los hechos supuestamente históricos que, mucho tiempo atrás, ya realizó Th. Zahn (1899: II 243-245).

13 Nunca es posible entrar en el proceso de intenciones de un exégeta. Sin embargo, tenemos la sensación de que la interpretación de Neirynck se debe al escándalo que le produce visualizar la total desnudez del muchacho. De hecho, ofrece algunos paralelos en los que varios personajes que quedan desnudos están, según su interpretación, en ropa interior: "También él se quitó sus vestidos y se puso en trance profético

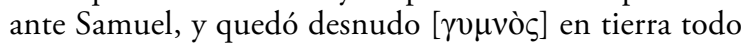
aquel día y toda aquella noche». (1Sam 19, 24). Más verosímiles son los siguientes ejemplos: «El discípulo a quien Jesús amaba dice entonces a Pedro: «Es el Se-

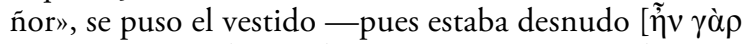

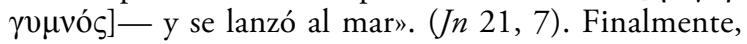

ofrece un testimonio clásico: «Nudus ara, sere nudus». (Verg. Georg. I 299). Es cierto, que no resultaría verosímil que un pescador o que un labrador trabajaran completamente desnudos. Con todo, lo más verosímil es que la imagen que quiere transmitir el evangelio es, precisamente, la de un muchacho totalmente desprovisto de ropa.

14 Tal idea procede de que el término $\sigma i v \delta \omega ́ v$ puede significar contextualmente "ropa interior de lujo» (Prov 31, 22; 24). De hecho, no es un término frecuente en la literatura veterotestamentaria: solo se documenta además en Jue 14, 12. Sin embargo, tal interpretación es puramente circunstancial. Otros comentaristas, consideran, al contrario, que el joven era un asceta penitente: "Some think that his having no other garment than this linen cloth upon his naked body, intimates that he was one of those Jews who made a great profession of piety that their neighbours, in token of which, among other instances of austerity and mortification of the body, they used no clothes but one linen garment, which, though contrived to be modest enough, was thin and cold". (Matthew Henry's Commentary, ad Mc 14, 43-52). En: https:// www.biblegateway.com/resources/matthew-henry/ Mark.14.43-Mark.14.52. (Online). 
nuestro juicio, todo esto no es sino un ejercicio de vacua erudición que, en realidad, pierde de vista el fondo de la cuestión y en nada contribuye a dilucidar el sentido del relato: como veremos, el pa-

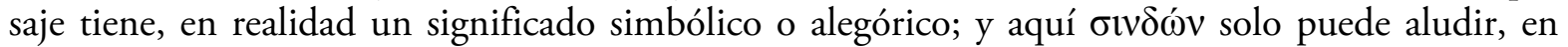
realidad, a la única $\sigma ı v \delta \omega ́ v$ de la que saben los primitivos textos cristianos, la sábana con la que fue amortajado el cadáver de Jesús (cf. $M c 15,46 ; M t 27,59 ; L c 23,53) .{ }^{15}$

En contraste, y ya en tiempos más recientes, la opción de muchos otros exégetas ha sido la de considerar que se trata de una figura simbólica. Así, el comentario de Moloney (2002), lo mismo que Brown (2003, 108-109), señala la posibilidad de que el muchacho sea, en realidad, un trasunto metafórico del conjunto de discípulos que abandonan a Jesús:

The young man is a model of the disciples as a group. His association with the disciples is in-

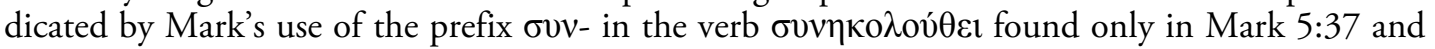
Luke 23:49 (...) He is not only "with» the disciples in following Jesus, but also with them in their flight. He leaves the linen cloth behind and flees naked. (F. J. Moloney, 2002).

En: http://www.wtsbooks.com/common/pdf_links/9780801048418.pdf (Online)

Ahora bien, ¿y si el personaje, en realidad, no se hallara aislado en el relato? ¿Y si pudiera ser identificado con alguna otra figura presente en la narración de Marcos? Tras los reiterados fracasos de la crítica tradicional a la hora de identificar al muchacho, tal propuesta contribuiría a aclarar sustancialmente el problema: al menos contaríamos con un elemento adicional que podría contribuir a solventar el enigma de su presencia en la escena del prendimiento. Y en efecto, este no es el

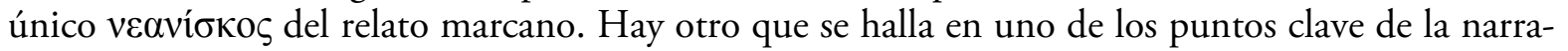
ción. Nada menos que el joven que entra en diálogo con las mujeres tras la resurrección de Jesús:

Y muy de madrugada, el primer día de la semana, a la salida del sol, van al sepulcro. Se decían unas a otras: «¿Quién nos retirará la piedra de la puerta del sepulcro?»Y levantando los ojos ven que la piedra estaba ya retirada; y eso que era muy grande. Y entrando en el sepulcro vieron a un joven

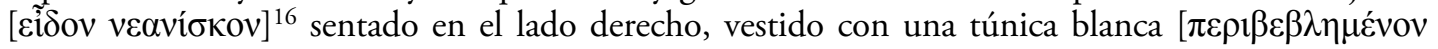

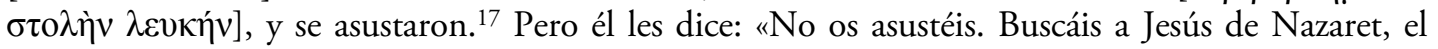
Crucificado; ha resucitado, no está aquí. Ved el lugar donde le pusieron.» $(M c 16,2-6)$

A nuestro juicio - $-\mathrm{y}$ en esto no somos originales—, la conexión es obvia: nos hallamos ante un

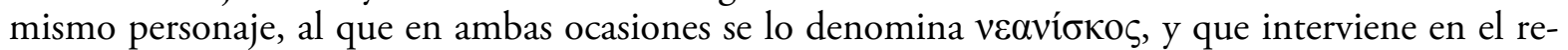
lato fundacional cristiano en dos momentos muy significativos: en un primer momento, en la escena del prendimiento, queda despojado de sus ropas; posteriormente, y tras la resurrección, aparece revestido de una túnica resplandeciente. Y ello no puede ser casual. ${ }^{18}$

\footnotetext{
15 Juan, en cambio, no alude a esta sábana, sino

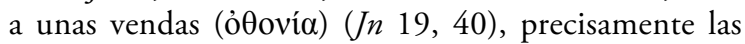

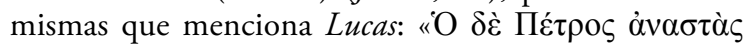

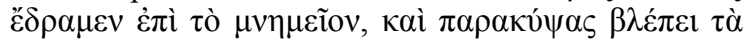

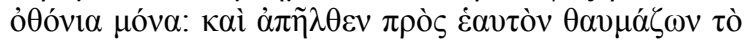

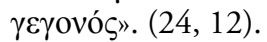

16 Sin artículo ni ningún determinativo. ¿Quizás indicio de un posible arameísmo?

17 Como consigna el comentario de Benoit y Boismard (1977, II 415), el final del versículo es un reflejo
}

de un pasaje de Daniel: «Los hombres que estaban conmigo no veían la visión, pero un gran temblor les invadió y huyeron a esconderse.» $(10,7)$, lo cual es un claro indicio del género escatológico en el que se inscribe el relato de la resurrección.

18 La exégesis tradicional y también la moderna crítica tienden, en general, a ver a dos individuos distintos (de Villiers 2010). En cambio, propuestas más recientes apuestan por identificarlos: así, Johnson (1999, 170178) y Thorday $(2005,63-72)$ también conectan ambos 


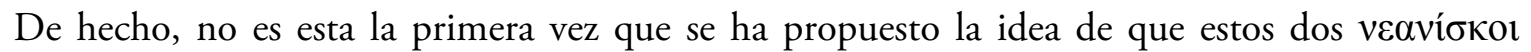
corresponden, en realidad, a un solo personaje. Así, Vanhoye (1971, 401-406) y, muy brevemente Crossan (1974, 147-148); pero, sobre todo, Scroggs y Groff (1973, 531-548), quienes formularon la hipótesis de que el personaje desdoblado constituía una alegoría del bautismo cristiano: la desnudez del muchacho evocaría la desnudez del candidato al bautismo despojado de sus viejas ropas, que serán sustituidas por una túnica blanca en el amanecer de la Pascua, símbolo de su nueva condición espiritual ( $c f . J n 3,5-7)$, concepto también manejado por Pablo: ${ }^{19}$

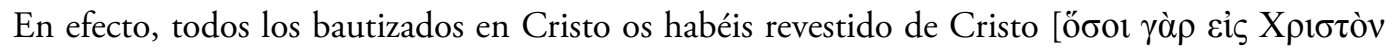

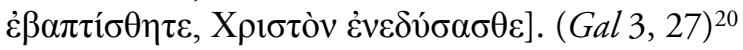

Por otra parte, Tate $(1995,69)$ conecta la desnudez del joven con la del endemoniado de Gerasa, quien, sanado por Jesús, acaba vestido y en su sano juicio $(M c 5,1-20)$. Esta idea se desarrolla con más énfasis en el trabajo de de Villiers (2010), quien centra su explicación del pasaje en la noción del poder de transformación vital que comporta el contacto con Jesús. ${ }^{21}$

Todo esto, por supuesto, no es ningún obstáculo para admitir que el pasaje pueda tener sus propias fuentes veteroestamentarias. Así, ya se ha señalado en otras ocasiones que el personaje podría ser un desarrollo de algunos pasajes proféticos (Klostermann, 1950, 153; Lane, 1974, 527; Schenk,

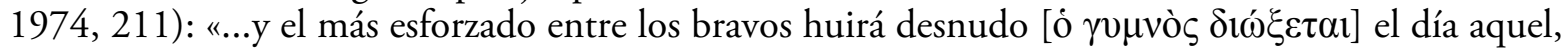
oráculo de Yahveh». (Am 2, 16); "22 "Sois vosotros los que contra mi pueblo como enemigos os alzáis. Al irreprochable le arrancáis el manto». (Miq 2, 8). Muy antigua, y ya sostenida por los padres de la Iglesia (p. ej. Ps.-Jerónimo apud Catena aurea de Tomás de Aquino, 1851, ad Mc 14, 52), ${ }^{23}$ es la idea de que el relato es un eco de la historia de José con la mujer de Putifar (Gen 39, 12), hipótesis defendida en época moderna por Waetjen $(1965,120)$, quien pone en paralelo nuestro episodio con la huida de José sin manto y su posterior exaltación, marcada por la rica vestidura de lino que le impone el Faraón (Gen 41, 44). ${ }^{24}$

pasajes. Johnson no explica los vínculos entre ambos pasajes; en cambio, Thorday suministra varios argumentos: en particular, el empleo del término veavíoкos y las obvias conexiones en el motivo de la desnudez y el vestido. En contraste, Gnilka $(2005,319)$ no solo apuesta

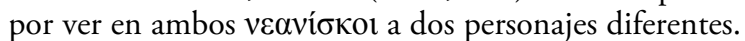
Más aún, tilda de fantasiosa la conexión que Vanhoye realiza entre ambos.

19 En una línea muy similar, McVann (1994, 179198).

20 No muy distante de esta hipótesis, aunque, en rigor, con menos argumentos, es la propuesta de Gourgues (1981, 672-678), según el cual Jesús ofició algún tipo de ceremonia nocturna de tipo mistérico en la que los iniciados portarían la esperable vestimenta blanca propia de tales ritos. Un examen de los ritos de la vigilia bautismal de Pascua en el cristianismo primitivo, en Yarnold (1972, 15-36). Por otra parte, de Villiers niega de plano, mas sin pruebas, esta interpretación: "The problem with this symbolic explanation is that people were not undressed when they were baptised. The image does not really 'fit' baptism». (2010, n. 7).
21 Con todo, cabe recordar que en Marcos no se explicita que el endemoniado anduviera desnudo - cosa que sí se dice en Lucas: «Desde hacía mucho

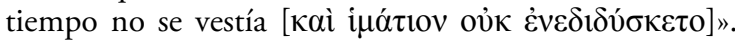

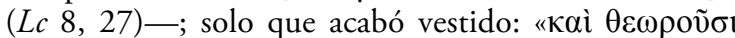

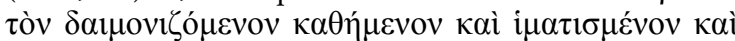
$\sigma \omega \varphi \rho o v o \tilde{v} \tau \alpha »$. $(M c 5,15)$. No obstante, el empleo de

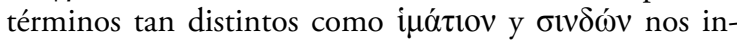
duce a considerar que tal conexión es más que discutible.

22 Sin embargo, como señala acertadamente Gnilka (2005, II 316), "hay que tener presente que Amós no juega papel alguno en todo el relato de la elaboración teológica de la pasión».

23 «Hieronymus: Sicut etiam Ioseph, relicto pallio, nudus de manibus impudicae feminae aufugit, qui vult effugere manus iniquorum, relinquens mente quae mundi sunt, fugiat post Jesum». (Cat. aur., ad Mc 14, 52).

24 Por su parte, Jackson se centra en la funcionalidad literaria del motivo y señala que la huida del joven tras perder sus ropas responde a una escena estereotipada en la literatura antigua. Así, comenta varios ejemplos que incluyen el topos y que acentúan dra- 
Hacemos un alto en nuestra exposición y reiteramos una idea que, por sabida, no ha de ser nunca olvidada en el análisis de los textos neotestamentarios: el hecho de que la inmensa mayoría de sus episodios, por más que tengan una apariencia fáctica, ha de ser explicada en clave simbólica o como un desarrollo exegético del Antiguo Testamento. Esto es, más que reflejo de un acontecimiento acaecido en el plano de la realidad, nos hallamos ante relatos que tratan de expresar una vivencia específica de las primitivas comunidades cristianas, vivencia que acabará siendo elevada a la categoría de lo teológico. Nos hallamos, pues, ante una manifestación de lo que podríamos denominar "teología narrativa»: el autor evangélico se sirve de un episodio de corte mitológico, que muchas veces es un desarrollo del Antiguo Testamento, para dar cuenta de una verdad teológica que aquí solo se reconstruye desde la exégesis, aunque tenía que resultar evidente en el contexto misionero originario.

\section{UNA NUEVA HIPÓTESIS EXEGÉTICA ACERCA DEL NEANISKOE MARCANO}

Tras este rápido repaso por las principales propuestas formuladas hasta la fecha acerca de la posible identidad del misterioso joven, es momento ya de que adelantemos nuestra hipótesis. Y es que, a nuestro juicio, y tal como vamos a tratar de demostrar en estas páginas, el enigmático muchacho de los dos relatos marcanos no es sino la propia realidad crística de Jesús.

De hecho, la idea de que ambos personajes sean trasunto de la propia figura de Jesús no es nueva. Así, Marcus $(2011,1302)$ consigna, aunque sin ofrecer ninguna referencia concreta, que ha habido quienes, como nosotros, han querido ver en el personaje al propio Jesús marcano en su dimensión crística, idea que desecha sin contemplaciones:

Aparte del hecho de que Marcos no proporciona indicación explícita alguna de como identificar a estos dos neaniskoi, el problema principal de esta teoría es la separación entre el comportamiento lleno de pánico del joven y el valor demostrado por Cristo, valor que se espera también de los cristianos. El joven huye de Jesús para salvar su vida, mientras que se espera que los cristianos permanezcan fieles a Jesús incluso ante la amenaza de la muerte (cf. 8, 34-38). Como afirma Morton Smith: «Esta interpretación olvida los hechos principales: este joven abandonó a Cristo y se salvó».

Ahora bien, la argumentación de Marcus quien, al menos en este punto, sigue a Smith (1982, 457 , n. 19), dista de ser satisfactoria. Y es que, por más que la reconstrucción psicológica de los sentimientos del joven pueda resultar verosímil, ${ }^{25}$ el argumento sigue sin explicar la presencia en la dramática escena de un muchacho cubierto por una mortaja.

En rigor, la única referencia que hemos hallado en nuestra indagación sobre la cuestión se halla en el siguiente pasaje de Rius-Camps: ${ }^{26}$

máticamente la tensión en una situación de violencia $(1997,285)$. De todas formas, el propio Jackson desecha la idea de que el texto se halle basado en el módulo retórico grecorromano. Como dice acertadamente, se trata de un motivo común que da vigor a la narración.

25 Tan verosímil como la explicación del comentario elemental de Bright: "He had followed Jesus and the disciples to the garden because he was curious». (en: http://www.easyenglish.info/bible-commentary/ mark-lbw.htm). Con todo, es la misma hipótesis que se manifiesta en Pesch (1977, II 402).

26 En rigor, tal identificación también es mencionada de pasada por el comentario de Benoit y Boismard (1977, II 415). No obstante, se trata de una breve alusión en la que se ponen de manifiesto los paralelos léxicos entre los dos pasajes marcanos, sin ningún tipo de explicación adicional. 
Su función en la escena, según el Códice Beza, es la de un doble que sustituye a Jesús para indicar que, si bien materialmente lo apresaron, solamente apresaron su mortaja. (...) En la escena del sepulcro aparece ese personaje. (...) [Las mujeres] al entrar vieron un joven sentado a la derecha (de Dios, sic!) envuelto en una túnica blanca. $(2008,194)$

No podemos estar más de acuerdo con las afirmaciones del estudioso catalán. Con todo, salvo con su lectura «a la derecha (de Dios)», que, desde luego, no se halla en ningún texto conocido y, a nuestro juicio, resulta excesivamente aventurada. ${ }^{27}$ No obstante, estas son las únicas palabras que dedica a la cuestión y, como veremos, nosotros vamos a tratar de llegar más lejos que él en nuestra interpretación; $y$, sobre todo, a intentar explicar argumentadamente la función de estos dos

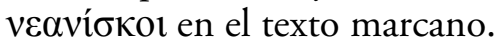

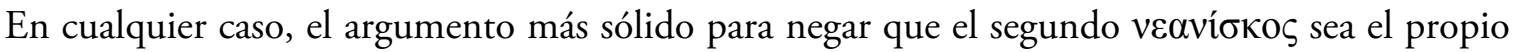
Cristo estriba en sus propias palabras, en las cuales habla de Jesús en tercera persona:

Pero él les dice: «No os asustéis. Buscáis a Jesús de Nazaret, el Crucificado; ha resucitado, no está aquí. Ved el lugar donde le pusieron. Pero id a decir a sus discípulos y a Pedro que irá delante de vosotros a Galilea; allí le veréis, como os dijo.» Ellas salieron huyendo del sepulcro... (Mc 16, 6-8)

En efecto, las inequívocas palabras del misterioso joven lo identifican como un individuo que, $a$ priori, no puede ser Jesús. Es un mensajero que informa a las mujeres ${ }^{28}$ de que el resucitado se hará presente entre sus discípulos en Galilea, tal como se narra en los textos de Mateo y Juan. ${ }^{29}$ Sin em-

\footnotetext{
27 Obviamente, la reconstrucción del escriturista catalán se debe al esperable contexto apocalíptico en el que sitúa el episodio, tal como se refleja también en las propia confesión de Jesús ante el Sumo Sacerdote: “'EEres tú el Cristo, el hijo del Bendito?’ Y dijo Jesús: 'Sí, yo soy, y veréis al Hijo del hombre sentado a la

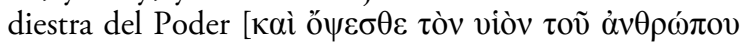

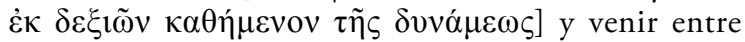
las nubes del cielo'.» (Mc 14, 61-62). Exactamente el mismo motivo que se refleja en las postreras palabras de Esteban: «Estoy viendo los cielos abiertos y al Hijo del hombre que está en pie a la diestra de Dios [íoov̀

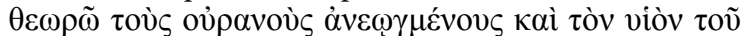
$\dot{\alpha} v \theta \rho \omega ́ \pi 0 v \dot{\varepsilon} \kappa \delta \varepsilon \xi 1 \tilde{\omega} \nu \tau o \tilde{v} \Theta \varepsilon \circ \tilde{v} \dot{\varepsilon} \sigma \tau \tilde{\omega} \tau \alpha] . »$ (Hchs 7, 55-56). Por otra parte, como señala el comentario de Benoit y Boismard (1977, II 416), «en 16, 5 encontramos al joven 'sentado a la derecha vestido con una túnica blanca' ¿Por qué sentado a la derecha? ¿Y a la derecha de quién o de qué? La expresión (...) debe de tener un sentido simbólico y debe aludir al Sal 110, 1, en que Dios dice al rey mesiánico 'siéntate a mi derecha'.»

${ }^{28}$ Nuestra convicción es que el relato de las mujeres en el sepulcro es una ficción literaria posterior a Pablo, quien no parece saber nada de ninguna tumba vacía ( $c f$. 1 Cor 15, 5-8). De hecho, la caracterización de la tumba de Jesús en Jerusalén indica que su existencia es meramente legendaria y su descripción estereotipada: así, ya estaba predicho en Isaías que el Mesías, siervo doliente,
}

acabaría enterrado en la tumba de un rico: «¿Qué es tuyo aquí y a quién tienes aquí, que te has labrado aquí

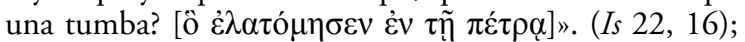
«Fue arrancado de la tierra de los vivos; por las rebeldías de su pueblo ha sido herido; y se puso su sepultura entre

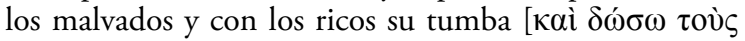

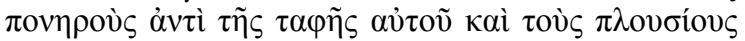

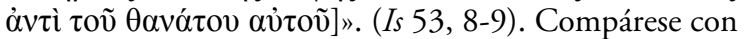
la caracterización de los evangelios: «Al atardecer, vino

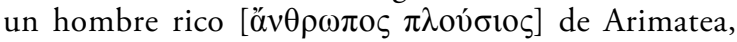
[...] Se presentó a Pilato y pidió el cuerpo de Jesús. Entonces Pilato dio orden de que se le entregase. José [...] lo puso en su sepulcro nuevo que había hecho exca-

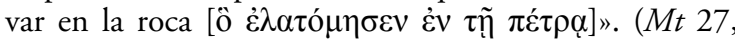
57-60). No obstante, muchos exégetas de corte tradicional siguen interpretando el motivo en términos históricos. Así, Myllykoski $(2002,61)$ sostiene que la tumba de Jesús es una realidad histórica y que, efectivamente fue enterrado en una lujosa tumba de tipo acrosolium, lo cual explicaría, a su juicio, la expresión «en el lado derecho" (Mc 16, 5). Sin embargo, manifestamos nuestras muy serias dudas sobre la cuestión y consideramos que el relato es un midrás destinado a desarrollar las correspondientes profecías veterotestamentarias.

${ }^{29}$ El motivo se hace más explícito todavía en $\mathrm{Ma}$ teo $(28,16-20)$, en donde, lejos de narrar las apariciones acaecidas en Jerusalén, el evangelista se limita a relatar una única aparición en Galilea. A nuestro juicio, 
bargo, no es esta la única ocasión, ni mucho menos, en la que Jesús adopta la tercera persona para hablar de sí mismo:

Jesús le respondió: 'Las zorras tienen madrigueras y las aves del cielo nidos, pero el Hijo del Hombre no tiene dónde recostar la cabeza'. (Mt 8, 20; cf. Lc 9, 58)

$\mathrm{Y}$ entonces verán al Hijo del hombre que viene entre nubes con gran poder y gloria; entonces enviará a los ángeles y reunirá de los cuatro vientos a sus elegidos, desde el extremo de la tierra hasta el extremo del cielo. (Mc 13, 26-27)

Mirad que subimos a Jerusalén, y el Hijo del hombre será entregado a los sumos sacerdotes y a los escribas; le condenarán a muerte y le entregarán a los gentiles, y se burlarán de él, le escupirán, le azotarán y le matarán, y a los tres días resucitará. $(M c 10,33-34)$

Obsérvese que las citas recogidas corresponden a profecías de Jesús en uso de sus atribuciones mesiánicas. ¿Y qué condición más mesiánica que la de haber vencido a la muerte en su prodigiosa resurrección? De hecho, esta tercera persona que adopta Jesús en estos pasajes les confiere un tono hierático y solemne que enfatiza su mensaje. El primero de los pasajes corresponde a la Fuente $Q$, el más antiguo de los textos que produjo el naciente cristianismo. Los otros dos forman parte de Marcos y son también sumamente antiguos. Mc 13, 26-27 está posiblemente formado en torno al año 40, con ocasión del escándalo de la instauración de la estatua de Calígula en el Templo, horrenda blasfemia que venía a cumplir la profecía de $\operatorname{Daniel}(12,11 ; 9,27 ; 11,31)$ sobre la «abominación de la desolación»; la profecía de $M c$ 10, 33-34 habla de su propio destino. Y si es capaz de hablar aquí en tercera persona de su propia resurrección, es muy verosímil que, una vez alcanzada la plenitud de la gloria, mantenga esa misma actitud. ${ }^{30}$ Además, en el dramático contexto de misterio y temor que viven las mujeres resulta muy conveniente que Jesús resucitado se oculte ante ellas: al fin y al cabo, solo se manifestará en plenitud ante Pedro y el resto de los discípulos en las apariciones de Galilea, que, como es sabido, no aparecen en el texto genuino de este evangelio.

el conjunto de apariciones galileas constituye un bloque narrativo mucho más antiguo que el de las de Jerusalén (Lc 24, 36-49; Jn 20, 1-29). En este sentido, la aparición del lago del capítulo 21 de Juan pertenecería a un estrato redaccional más antiguo que la aparición jerosolimitana del 20. Por otra parte, no podemos dejar de consignar que ciertos relatos (p. ej. Jesús camina sobre las aguas) que, a día de hoy, se hallan en la sección «biográfica» de los evangelios son, en realidad una mixtificación de las leyendas originarias de las apariciones acaecidas tras la resurrección: «Ellos, al verlo caminar sobre el mar, pensa-

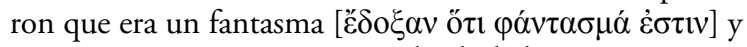
se pusieron a gritar, porque todos lo habían visto y estaban sobresaltados. Pero Él les habló enseguida y les dijo: 'Tranquilizaos, soy yo; no temáis'.» (Mc 6, 47-50; $c f$. Mt 14, 25-31; Jn 6, 19-20). Nos hallamos, pues, ante un relato que pertenecería al ciclo de las apariciones galileas. $\mathrm{Al}$ igual que el relato de la pesca milagrosa $(J n 21,1-14)$, el episodio ocurre en la barca, que más que un objeto real es un lugar teológico. La resurrección se manifiesta a través de un hecho extraordinario: Jesús camina sobre las aguas y sus discípulos reaccionan con el asombro correspondiente. Aquí se aprecia la mano del primer evangelista, pues no solo realizó un brutal desplazamiento del relato desde su ubicación originaria —el ciclo de las apariciones-, sino que se apresuró a dar cuenta de que el Jesús que veían sus discípulos no era un fantasma. Al fin y al cabo, semejante cosa no era nada tan extraordinario en el Mundo Antiguo, en el que la aparición de fantasmas y espectros de muertos era algo relativamente corriente. La resurrección era otra cosa.

30 Así lo hace en Lucas, en la aparición a los discípulos de Emaús, en donde al tiempo que exhibe su erudición escriturística al estilo de los propios misioneros cristianos (cf. Hchs 17, 1-4; 18, 24), adopta gesto solemne y habla de sí mismo en la misma tercera persona: «El les dijo: ‘ $\mathrm{O}$ insensatos y tardos de corazón para creer todo lo que dijeron los profetas! ¿No era necesario que el Cristo padeciera eso y entrara así en su gloria?' Y, empezando por Moisés y continuando por todos los profetas, les explicó lo que había sobre él en todas las Escrituras». (Lc 24, 25-27). 
Con todo, la prueba más significativa de que el personaje que está hablando no es un ángel, sino el propio Jesús, es el hecho de que en el Codex Bezae quedan restos textuales muy evidentes que manifiestan que el autor de Marcos manejó algún texto previo en el que el muchacho de la tumba era, en efecto, el resucitado, tal como señala muy acertadamente J. Rius-Camps:

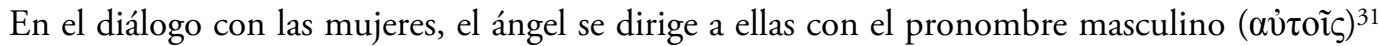
y pasa insensiblemente de la tercera persona del singular a la primera, hablando como si fuera Jesús en persona. (Rius-Camps 2008, 195)

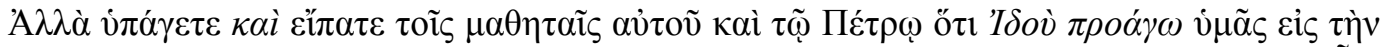

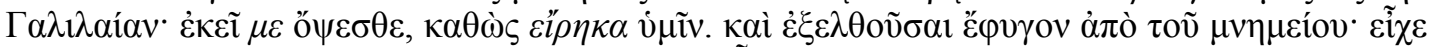

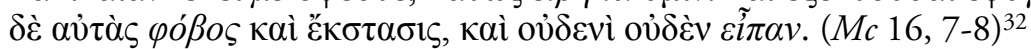

Nos hallamos, pues, y tal como defiende el estudioso catalán, ante un estadio redaccional de Marcos previo al que suministra el tipo alejandrino, sobre el que se basa el texto estándar. Más aún, nos hallamos ante la prueba tangible de que en los relatos más antiguos forjados por el cristianismo primitivo era Jesús mismo quien se manifestaba, y posiblemente ante unos varones (av̉ioĩs). Solo después, se acuñó el motivo de la tumba vacía, ${ }^{33}$ la visita de las mujeres y el mensaje del ángel. Y es que no podemos perder de vista que la totalidad de los relatos de las apariciones tras la resurrección -incluido el del propio Marcos - son desarrollos narrativos que dependen de una leyenda seminal más antigua que, seguramente, se perdió entre el tráfago de las primeras décadas del cristianismo en las que dos generaciones de predicadores multiplicaron y amplificaron los sencillos y esquemáticos relatos iniciales. Así, y gracias a las escuetas informaciones paulinas (1Cor 15, 6; Rom 16), sabemos que el resucitado de las primeras décadas se estuvo apareciendo a mucha gente, a lo largo de mucho tiempo y, seguramente, de muchas maneras. ${ }^{34}$ Sus comunicados no quedaban restringidos a las mujeres y a los discípulos de los relatos canónicos. ${ }^{35}$ Seguramente, hubo muchos más «testigos de la resurrección» ( $c f$. Hchs 1, 22) y, sin duda, muchos más relatos de lo acaecido en su tumba, que, además, es un relato de corte teológico del que autores tempranos como Pablo todavía no tienen noticia.

31 Por supuesto, la ed. de Nestle-Aland (26) considera que se trata de un mero error de copista.

32 Compárese con el texto del tipo alejandrino:

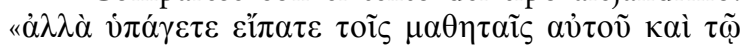

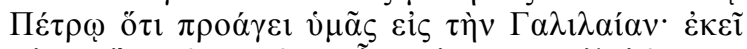

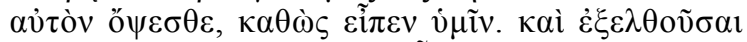

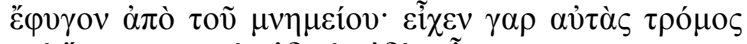

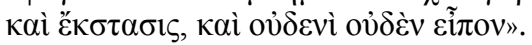

33 En rigor, en Marcos la tumba no está vacía, ya que

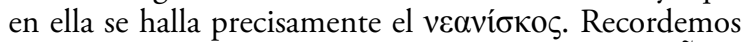

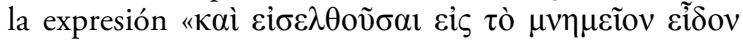

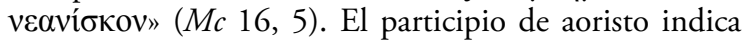
que las mujeres solo vieron al joven después de haber entrado en la tumba.

${ }^{34}$ De hecho, así lo parecen confirmar algunas noticias paulinas (1Cor 15, 6; Rom 16, 7). Más aún, el famoso pasaje de Suetonio relativo a la expulsión de los judíos de Roma decretada por Claudio — «Iudaeos, impulsore Chresto, assidue tumultuantes [Claudius] Roma expulit». $(\mathrm{Cl} .25,4)$ - es un claro indicio de que la primerísima predicación judeo-cristiana en la capi- tal del Imperio iba acompañada de apariciones del resucitado que generarían los correspondientes altercados y tumultos en las sinagogas de la ciudad (Fontana 2014b, 316-320).

35 Esto es, es muy probable que el resucitado estuviera manifestándose durante las primeras décadas del movimiento en una multitud de apariciones. Tiempo después, y ya pasada la intensa y anarquizante fase carismática propiciada por la tensión escatológica, dejó de aparecerse; y para ello, ya en el siglo II, se creó el teologúmeno de la ascensión (Hchs 1, 9-12), que, de un lado, venía a justificar la ausencia de apariciones; $y$, de otro, propiciaba una mejor recepción entre los conversos procedentes del paganismo. En efecto, aunque ya existen precedentes judíos del fenómeno - el rapto de Elías (2Re 2, 1-14) o las ascensiones de la literatura intertestamentaria-, se trata también de una realidad muy bien conocida en la literatura grecorromana (Ovid. Met. XV 843-851; Sen. Apoc. 1). Un examen de las semejanzas y diferencias entre los párrafos iniciales de Hechos y la Apocolocyntosis de Séneca, en Dormeyer y Galindo (2007, 42-43). 
O de otra manera, es muy posible que en el relato más antiguo de la resurrección, creado acaso en los años inmediatamente anteriores a la redacción del propio Marcos (ca. 75), el muchacho de la tumba fuera, efectivamente, como sostenemos, la plasmación de la propia realidad de Jesús en su plenitud vital. Recordemos a este respecto el reiterado motivo de los textos canónicos, en los cuales Jesús, muchas veces, resulta irreconocible ante los destinatarios de sus apariciones (cf. Lc 24, 13-35; In 20, 14-16; 20, 24-29). Sin embargo, tiempo después, el misterioso joven quedó equiparado literariamente con una figura angélica. Ello es más evidente en Lucas y, sobre todo, en Mateo. En cambio, en Marcos, el más antiguo de los evangelios, todavía quedarían rastros evidentes del relato primitivo, aunque ya no resulten reconocibles a primera vista: ${ }^{36}$ el propio Cristo, liberado en el prendimiento de las manos de sus captores, reaparecería vivo y triunfante ante las mujeres que acudieron a embalsamarlo.

Así pues, y según nuestra hipótesis, el personaje fue creado por la primitiva tradición cristiana como una figura de poderosísimo carácter simbólico: nada menos que la de la realidad crística de Jesús, quien iba a hurtarse a la muerte que le preparaban sus captores, los cuales solo se iban a quedar con la mortaja ( $\sigma \iota v \delta \omega ́ v)$, esto es, con su cuerpo. Era su manera de explicar que la cruz no iba a acabar definitivamente con la vida del Señor. Y lo que es más, unos días después, ese mismo individuo se manifestará ante las mujeres revestido ya de la túnica blanca que indica su entrada en la gloria, ${ }^{37}$ recurso literario ampliamente conocido en la literatura cristiana primitiva: «Ẻv i $\mu \alpha \tau i ́ o 1 \varsigma$

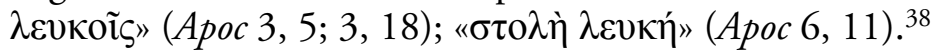

A este respecto, recordemos las propuestas exegéticas que, ya desde la Antigüedad, interpretaban el acto de cubrirse con pieles de Adán y Eva como un símbolo de la adquisición de la carnalidad. El hombre en el Paraíso era, en realidad, un espíritu puro que solo se revistió de materia tras haber pecado:

\footnotetext{
36 Somos conscientes de que, en nuestra argumentación, nos apartamos del consenso exegético, que considera que el relato de la aparición a las mujeres es anterior al ciclo de las apariciones galileas narradas por Juan. Dejamos, pues, que sea el lector quien juzgue la verosimilitud de nuestra hipótesis.

37 Un problema adicional es el misterio de dilucidar en dónde o en qué estado se halló la realidad crística de Jesús entre su muerte y su resurrección. Así, a fines del siglo I, Efesios $(4,9)$ menciona que Cristo «bajó a las regiones in-

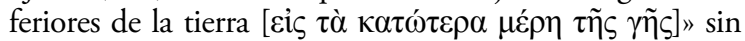
dar más explicaciones. En cambio, unas décadas después, la tardía Primera carta de Pedro afirma que, tras su muerte, Cristo también predicó en el Hades: «Pues también Cristo, para llevarnos a Dios, murió una sola vez por los pecados (...). En el espíritu fue también a predicar a los espíritus encarcelados, en otro tiempo incrédulos, cuando les esperaba la paciencia de Dios». (1Pe 3, 18-20). En rigor, la idea de que Cristo predicó en los infiernos a las almas es francamente novedosa. El comentario de Elliott (2013, 122-123) contextualiza el pasaje en el marco de la literatura judía intertestamentaria, y en particular lo vincula con IHenoc, obra en la que aparecen una serie de visiones de Henoc el Justo. En estas, el protagonista dice haber ascendido desde la tierra y haber avanzado a través de una serie de cielos, viaje en el que Dios le encomienda que comunique a los espiritus angélicos antediluvianos la con-
}

dena que les había impuesto. IHenoc 6-11 narra la caída de esos espíritus angelicales y su prisión. En paralelo $1 P e$ 3, 19-20 presenta a Jesucristo resucitado como un Henoc de los últimos días. Por otra parte, y a modo de simple curiosidad, mencionamos que la única consecuencia que conocemos del mito es la idea sostenida por Tertuliano relativa a la controversia acerca del momento en que el alma pasará a gozar de la visión beatífica. Así, este consideraba que las almas de los justos no entrarían en el Paraíso hasta el día del juicio. Hasta ese momento, quedarían hospedadas en un seno delicioso (Apol. 47, 13), en donde Dios se dejaría ver tal como Cristo se dejó ver por los patriarcas cuando bajó al Hades. (De anim. 7, 3).

38 Otra de las manifestaciones literarias del motivo se halla claramente en el relato de la transfiguración: «Y mientras oraba, la apariencia de su rostro se hizo otra, y su vestido blanco y resplandeciente [ó i $\mu \alpha \tau t \sigma \mu o ̀ \varsigma \alpha u ̛ \tau o \tilde{~}$ $\lambda \varepsilon v \kappa o ̀ \varsigma ~ \varepsilon ̇ \xi \alpha \sigma \tau \rho \alpha ́ \pi \tau \omega v] » .(L c 9,29)$. Por otra parte, el motivo de la túnica limpia como símbolo de la pureza de los salvados que no han cedido a la carne aparece implícitamente en otros textos cristianos de matriz judía. Tal es el caso de la Carta de Judas (23), quien condena a los cristianos que, habiendo recibido la túnica de la salvación, no obstante, la han mancillado por la corrupción pecaminosa de la carne: «y a otros mostradles misericordia con cautela,

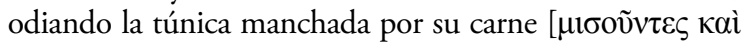

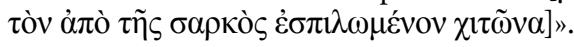


«A semejanza» se refiere al [hombre] psíquico, de donde su substancia es denominada también espíritu de vida (Gen 2, 7), pues proviene de una emanación espiritual. Finalmente, vino revestido de

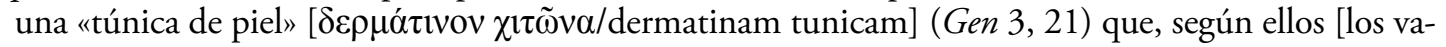
lentinianos], significa la carne sensible. (Iren. Adv. Haer. I 5, 5) [trad. J. Montserrat Torrents]

Por supuesto, tales doctrinas no son una creación del cristianismo. Ya estaban ampliamente difundidas en el propio judaísmo y, desde él, se extendieron al gnosticismo cristiano:

¿Por qué Dios vistió de pieles a Adán y a su mujer [Gen 3, 21]? (...) El manto de pieles es una expresión figurada de la piel natural, esto es, nuestro cuerpo. (Phil. Alex. Quaest. Gen. 53) ${ }^{39}$

Interim carnalem superficiem postea aiunt choico supertextam et hanc esse pelliceam tunicam obnoxiam sensui. (Tert. Adv. Val. 24, 3) $)^{40}$

Así pues, y de ser cierta nuestra conjetura, la mortaja ( $\sigma \imath \downarrow \delta \omega ́ v)$ que quedó entre las manos de quienes intentaron atrapar al muchacho no es sino un trasunto del propio cuerpo de Jesús, destinado a morir y quién sabe si a la propia corrupción (cf. 1Cor 15, 35-38).

Esta argumentación es la más evidente de las pruebas que demuestran la inanidad del debate relativo a si el joven había quedado desnudo del todo o solo en ropa interior. En el horizonte de expectativas simbólicas que estamos reconstruyendo, resulta obvio que la imagen del joven que huye comporta, en efecto, una total desnudez. De hecho, como consigna el comentario de Benoit y Boismard, en el cristianismo primitivo «el tema de la desnudez va unido al de la sepultura con perspectivas de una resurrección»:

Porque sabemos que si esta tienda, que es nuestra morada terrestre, se desmorona, tenemos un edificio que es de Dios (...) Y así gemimos en este estado, deseando ardientemente ser revestidos de nuestra habitación celeste, si es que nos encontramos vestidos, y no desnudos. ¡Sí!, los que estamos en esta tienda gemimos abrumados. No es que queramos ser devestidos, sino más bien sobrevestidos, para que lo mortal sea absorbido por la vida. (2Cor 5, 1-4; cf. 1Cor 15, 37)

¿Cómo y de qué manera se hace la siembra? Salió el sembrador y echó en la tierra cada una de

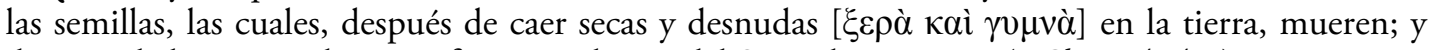
después de la muerte, la magnífica providencia del Señor las resucita. (1Clem 24, 4-5)

Más aún, el motivo de la desnudez se consolidó, tiempo después, en la simbología gnóstica como metáfora de la conquista de la condición plenamente espiritual por parte del creyente:

Dijo María a Jesús: «¿A quién se parecen tus discípulos?» Él dijo: «Son semejantes a unos nińos pequeños, instalados en un campo que no es suyo. Cuando vengan los dueños del campo dirán: Dejadnos nuestro campo. Ellos se desnudan en su presencia para dejárselo y devolverles su campo». (EvTom. 21)

Hay quienes tienen miedo de resucitar desnudos y por eso quieren resucitar en carne: estos no saben que los que están revestidos de carne son los desnudos. Aquellos que [osan] desnudarse son precisamente [los que] no están desnudos. (EvFlp. 23)

39 De la misma manera, y ya en la literatura talmúdica el cuerpo de Adán era un ente luminoso que irradiaba Divinidad (Bereshit Rabah 20, 12). Sin embargo, tras su pecado, aquel cuerpo de luz, quedó encerrado en un envoltorio de piel y cuero que ocultó su alma originaria (ibidem 20, 12).

40 Asimismo, Casiano (apud Clem. Alex. Strom. III 95, 2); Exc. Theod. 55. 
Por supuesto, en el estado actual de Marcos, el joven que aparece en la tumba está equiparado a los ángeles de Mateo $(28,2)$ o los misteriosos varones de Lucas $(24,4) .{ }^{41}$ Tal es la razón que explica por qué nuestro personaje, heredado de una tradición más antigua, habla de Jesús en tercera per-

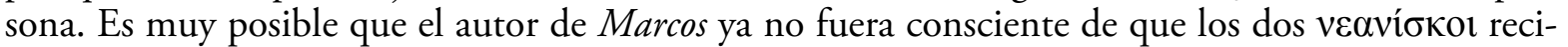
bidos en el viejo relato de la pasión del que se sirvió para construir su «biografía de Jesús» fueran, en realidad, el mismo personaje. ${ }^{42}$

Por otra parte, el hecho de que no hallemos trazas en los textos canónicos de la doctrina que aquí tratamos de defender, no significa que no existan indicios de ella en otros grupos cristianos primitivos:

Carpócrates y sus discípulos dicen que el mundo y todo lo que en él se halla fue creado por ángeles muy inferiores al padre ingénito, y que Jesús nació de José; semejante al resto de los hombres, fue superior a todos, pues su alma, vigorosa y pura como era, conservaba el recuerdo de lo que había visto en su movimiento circular en torno al Dios ingénito. Por esto le fue enviada por aquél una potencia para que pudiera escapar de los creadores del mundo. (Iren. Adv. haer. I 25, 1; trad. de J. Montserrat Torrents) ${ }^{43}$

La mera lectura de estas líneas evidencia que Carpócrates y sus seguidores, en una línea interpretativa de raigambre platónica, ${ }^{44}$ podrían haber considerado el pasaje del muchacho que huyó desnudo en términos muy semejantes a los que aquí proponemos. La diferencia fundamental es

41 En rigor, Mateo sí habla de un ángel; Lucas los

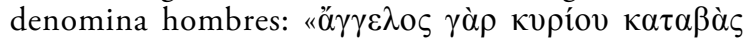

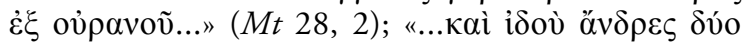
$\dot{\varepsilon} \pi \varepsilon \dot{\varepsilon} \sigma \eta\rceil \alpha \nu \alpha \hat{\tau} \tau \alpha \tilde{\iota})^{\prime}$. (Lc 24, 4). Juan, por su parte, habla ya de dos ángeles que, al parecer, han permanecido todo el tiempo velando a la cabecera y a los pies de Jesús (Jn 20, 12). De ser correcta nuestra interpretación, el pasaje sería un eco del relato apócrifo narrado en la Carta de Judas (9), en el que Miguel y el diablo pelean por el cuerpo de Moisés (relato procedente, a su vez, de la Asunción de Moisés, siglo I d.C.). En este caso, el cadáver de Jesús no se ha visto nunca en peligro porque él, que es superior a Moisés ( $c f . J n$ 1, 17; 5, 45-47; Hebr 1 , 4-14), ha sido protegido por estos ángeles. Por otra parte, el comentario de Marcus (2011, 1246; asimismo, Brown, 1994, 304) no vacila en identificar a este joven con una figura angélica. Ofrece bastantes paralelos bíblicos en los que los ángeles adquieren figura humana $\mathrm{y}$, en particular, poseen un aspecto juvenil (veavíaı): así, 2Mac 3, 26; 33 y Josefo $A J \mathrm{~V} 277$. Hemos de reconocer que la argumentación léxica es de peso. Con todo, consideramos que el conjunto de razones que hemos acumulado en el trabajo hace que nuestra interpretación no sea descartable a priori. Más aún, Marcos menciona ángeles en algunos de sus pasajes $(1,12 ; 12,25$; $13,32)$, pero en ningún momento los identifica como

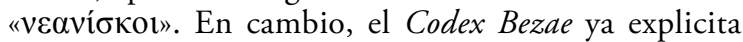

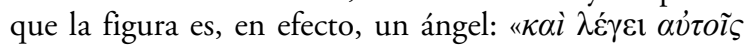

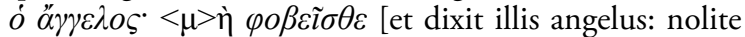

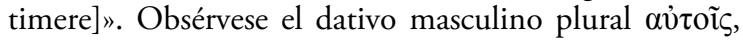

en lugar del femenino estándar av̉ $\alpha$ ĩ, lo cual evidencia que nos hallamos ante un estrato narrativo previo en el que el mensaje no estaba dirigido a las mujeres, sino directamente a los discípulos.

42 Por supuesto, en textos posteriores, la figura de los jóvenes ángeles se amplificó y cobró nuevas dimensiones: «Y durante la noche en la que iba a amanecer el día del Señor, mientras los soldados, de dos en dos, hacían guardia por turno, hubo una gran voz en el cielo. Y vieron que se abrían los cielos y a dos varones bajando de allí [cf. $M t 28,2$ ] con mucho resplandor y acercándose

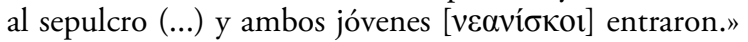
(EvPtr 9, 35-37). «Y mientras explicaban lo que habían visto, de nuevo vieron saliendo del sepulcro a tres varones, y dos sosteniendo a uno y una cruz siguiéndolos. Y la cabeza de los dos llegaba hasta el cielo, pero la del que era conducido por ellos sobrepasaba los cielos.» (10, 39-40) (trad. P. Edo)

43 De hecho, el Evangelio de Pedro modifica las últimas palabras del Jesús canónico y le hace proferir: «H

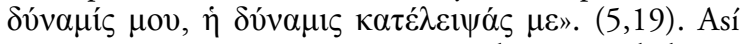
pues, y según nuestra interpretación, la comunidad cristiana que está detrás de esta narración consideraba que la entidad crística abandonó a Jesús en la cruz en el preciso instante antes de morir.

${ }^{4}$ En consonancia, los integrantes de la secta creían en la reencarnación («transmigrationes in corpora»), en la medida en que consideraban que los cuerpos de los hombres eran cárceles para las almas ( $c f$. Iren. Adv. haer. I 25,4$)$. 
que, para ellos, el muchacho de la escena del prendimiento sería una "potencia» (virtus), enviada desde la eternidad para salvar a Cristo de los poderes de este mundo ( $c f . J n 12,31) ;{ }^{45}$ y en cambio, según nuestra interpretación, es la propia realidad crística de Jesús la que se hurta a sus captores para reaparecer en plenitud tras la resurrección. Un indicio de ello sería la presencia en el pasaje del im-

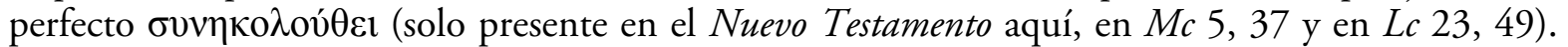
Con él, el autor no solo hace del muchacho un simple discípulo, es alguien que lo acompaña y con el que mantiene una relación de intimidad especial que se manifiesta en otros pasajes evangélicos:

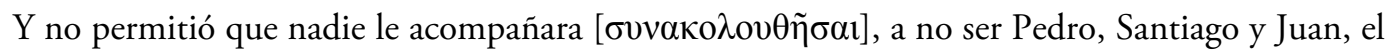
hermano de Santiago. (Mc 5, 37)

Nos hallamos, pues, ante una realidad muy semejante a otras bien conocidas en algunas re-

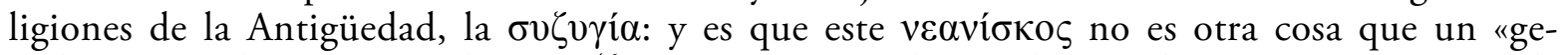

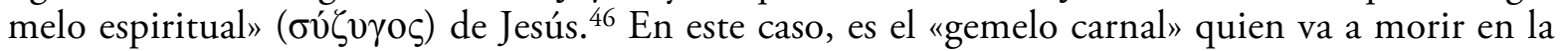

45 No es este el ámbito para profundizar en las complejísimas escalas ontológicas formuladas por los gnósticos. Bástenos señalar de pasada que estas "potencias» a las que alude el texto son, según Ireneo de Lyón, entidades subordinadas a Cristo $(A d v$. Haer. I 4, 5) que fueron creadas al mismo tiempo que él; y, al parecer, eran ángeles de su misma natu-

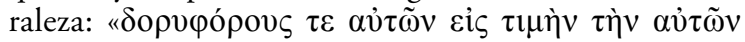
ó quoque ei, in honorem ipsorum, eiusdem generis angelos cum eo prolatos]». (Adv. Haer. I 2, 6). Por otra parte, es muy posible que nuestro muchacho desnudo, sea también el precedente del desconocido ángel lucano que consuela a Jesús en la agonía de Getsemaní (Lc 22, 39-43). Por otra parte, según Alonso Díaz y Vargas Machuca $(1996,268)$, el Evangelio de los $\mathrm{Na}$ zarenos contenía las palabras con las que el ángel confortó a Jesús: «Sé constante, Señor. Ahora ha llegado el tiempo en el que por tu pasión se ha de redimir el género humano".

46 De hecho, puede que el motivo cuente con paralelos en tradiciones religiosas del Medio Oriente mucho más antiguas. Así, según de Moor, en algunas de las versiones del mito de la resurrección de Baal, este, en realidad, no muere, sino que quien lo hace es un "hermano gemelo» $(m t)$ que Baal engendró con la novilla (KTU 1.5. V: 17-26): «Disfrazado como Ba'lu este descendiente morirá en su lugar, como si fuese una especie de sar pubi, el famoso substituto del rey de Babilonia. (...) Ba'lu experimentará una muerte aparente». (de Moor 1971, 188). De todas formas, esta interpretación del mito de Baal dista, y mucho, de ser aceptada entre los especialistas, quienes, ya desde el momento mismo de su publicación, la sometieron a las críticas más acerbas (así, Grabbe 1976,
57-63). Por otra parte, la tradición griega también conoció creencias relativamente parangonables. Nos estamos refiriendo a los fenómenos de bilocación o traslocación, merced a las cuales las almas de determinados personajes taumatúrgicos eran capaces de abandonar su cuerpo. Así, varios magos famosos tenían la facultad de hallarse - y ser vistos- en dos lugares a la vez, o bien la de trasladarse en asombrosos viajes en el espacio y en el tiempo. Como es sabido, Dodds (1986, 133 y ss.) es autor, en pos del trabajo de Meuli $(1935,121-176)$, de la conocida tesis de que estos personajes son la plasmación de figuras chamánicas de origen siberiano (reinterpretadas en el relato griego a través del mito de los hiperbóreos). Sin embargo, a día de hoy esta idea ha caído en el descrédito. Ahora bien, independientemente de eso, está claro que estas figuras (Ábaris, Epiménides, Pitágoras, etc.) mantuvieron un indiscutible prestigio a través de los siglos y, todavía en época imperial, estaba muy extendida la idea de que el mago podía desdoblarse - en viajes bien físicos, bien espirituales - a grandes distancias. El más antiguo de ellos es Aristeas de Proconeso (Hdto. IV 13-15; asimismo, Pind. fr. 284 Bowra). Tras él, podemos mencionar a Hermótimo de Clazomene, que era capaz de liberar durante el sueño las amarras que unían su alma a su cuerpo y viajar a regiones desconocidas (Plut. Gen. Socr. 592 C-E; Plin. NH VII 174). Al parecer, acabó por reencarnarse en Pitágoras, el cual también poseía esta facultad, pues fue capaz de mantener dos conversaciones simultáneas con sus discípulos en Metaponto y Tauromenio (Jambl. Vit. Pith. 27). Finalmente, el más célebre de los magos de la Antigüedad, Apolonio de Tiana, poseía también esta portentosa facultad (Filostr. Vit. Apol. IV 10). 


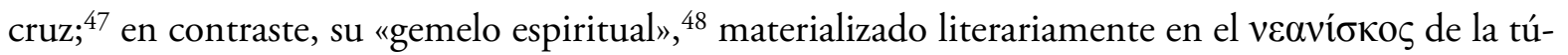
nica blanca, va a ser preservado hasta su manifestación en el sepulcro vacío.

Esto nos lleva a plantearnos una cuestión fundamental, mas imposible de tratar en profundidad en este trabajo: ¿qué entendía por «resurrección» la comunidad que dio lugar al relato del que partió el autor de Marcos? Frente a las apariciones de naturaleza corpórea de los evangelios posteriores - Jesús en carne y hueso $(L c 24,39)$; Jesús comiendo pescado ( $L c 24,43)$; Jesús mostrando las llagas a Tomás (Jn 20, 20-29) - el desconocido revestido de resplandeciente túnica es un ser trascendente que se ha despojado plenamente de su condición mortal, simbolizada a través de la mortaja. Más aún, no sería inverosímil que consideraran que su cadáver, al fin y al cabo un mero despojo, se había corrompido en la tumba (cf. 1Cor 15, 35-38). En rigor, todos los evangelistas tienen graves dificultades a la hora de expresar el hecho de la resurrección. Baste el ejemplo de Mateo:

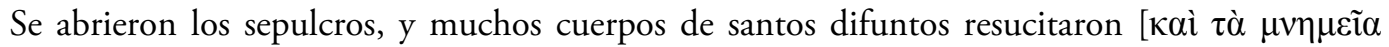

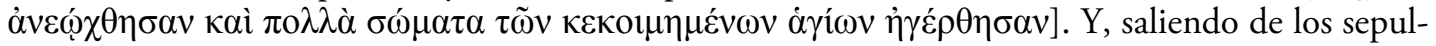

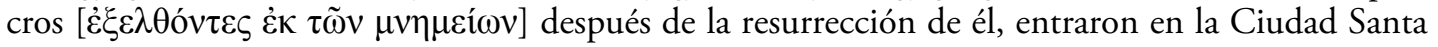

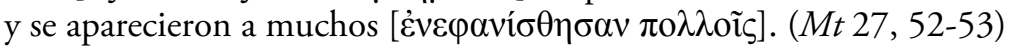

Aquí, el autor de Mateo da cuenta de cómo se aparecieron los santos resucitados tras la resurrección de Jesús. Otra cosa es la ambigüedad con la que se describe su condición. En efecto, los difuntos que abandonaron sus tumbas se aparecen, pero no regresan a vivir a sus casas, lo cual parece insinuar que carecían de cuerpo craso; como no craso en ocasiones es el cuerpo de Jesús (cf. Jn 20, 19: Jesús atraviesa paredes y puertas cerradas); y para ello el autor acude al concepto de aparición

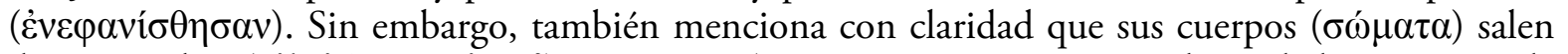

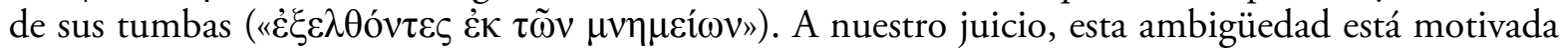
por el hecho de que lo extraordinario del acontecimiento le impide determinar en qué consiste la resurrección. ${ }^{49}$ No obstante, lo que sí está claro, al menos a nuestro juicio, es que el Cristo que se manifiesta en el relato de Marcos carece de las características corpóreas de los relatos posteriores. Se ha desprendido plenamente de su condición mortal, lo cual incluye la carne y las huellas de sus pa-

47 A este respecto, no podemos perder de vista que muchos gnósticos consideraban que la crucifixión y la muerte de Jesús solo habían sido aparentes, en la medida en que él, como ser divino, carecía de la condición mortal. Más aún, hubo quien como el autor del Segundo tratado del Gran Set (NHC VII 2) sugirió que fue Simón de Cirene quien realmente murió en la cruz en lugar de Jesús. No obstante, el texto no es del todo seguro: «Mi muerte, en efecto, que creen que sucedió existió para ellos ciega y equivocadamente. Clavaron a su hombre para la muerte de ellos. (...) Me flagelaban con la caña; otro era el que llevaba la cruz sobre su hombro, este era Simón». (trad. Piñero 2000, 177).

48 Por supuesto, el concepto de $\sigma v \zeta v \gamma i ́ \alpha$, como unión entre cuerpo y alma, es también conocido por el judaísmo del siglo I, tal como evidencia la siguiente

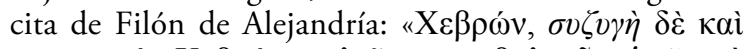

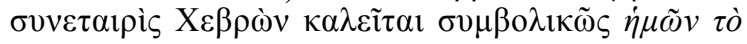

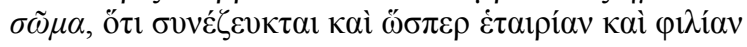

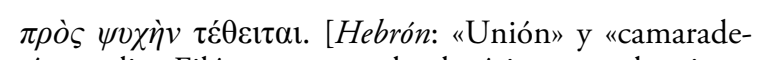
ría» - dice Filón comentando alegóricamente la etimología del valle del Hebrón (Gen 37, 14) — se llama simbólicamente nuesto cuerpo, porque está unido al alma y ha establecido con ella como una camaradería y amistad]». (Quod deterius potiori insidiari soleat 15; trad. de Coria 2010, 130). Como se ve, Filón designa el vínculo entre la dimensión corporal y espiritual del hombre con un término homónimo ( $\sigma 0 \zeta v \gamma \eta ́)$ al que nosotros hemos empleado ( $\sigma v \zeta v \gamma i ́ \alpha)$ a la hora de describir la realidad que Marcos trata de describir literariamente.

49 A tenor de la descripción paulina (1Cor 15 , $35-44 ; 15,52)$, los primeros cristianos creen en una resurrección que va más allá de una mera vivificación del cadáver. Se trata de la adquisición de un cuerpo inmortal, investido de una nueva naturaleza de carácter espiritual y ajena a la materia de este mundo. A este respecto, hemos de recordar que el judaísmo se halla al margen de la dicotomía platónica material/espiritual. 
decimientos, y se manifiesta como una realidad nueva e irreconocible para quienes lo conocieron en esta vida. ${ }^{50}$

Es cierto que ninguno de los textos del canon ofrece rastro alguno de la doctrina que aquí reconstruimos. Sin embargo, creemos que nuestra hipótesis justifica satisfactoriamente los problemas de los episodios marcanos sobre los que centramos nuestra atención. Evidentemente, carecemos de información sobre los motivos que indujeron a las comunidades a postergar tal doctrina; ${ }^{51}$ pero, en términos genéricos, hemos de suponer que interfería con otras incipientes formulaciones cristológicas protoortodoxas más avanzadas. ${ }^{52}$ En cualquier caso, no podemos perder de vista que su existencia se prolongó largo tiempo todavía en otras corrientes cristianas como el gnosticismo o el maniqueísmo:

50 Otra cuestión en la que no podemos profundizar es la relativa a la cristología que podía tener la comu-

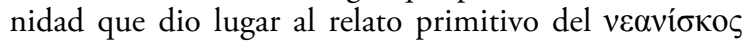
resucitado. Así, Robinson (1962, 139-153) traza una nítida distinción entre las dos cristologías que se manifiestan en los capítulos iniciales de Hechos: «Arrepentíos, pues, y convertíos, para que vuestros pecados sean borrados, a fin de que del Señor venga el tiempo de la consolación y envíe al Cristo que os había sido destinado, a Jesús, a quien debe retener el cielo [ôv $\delta \varepsilon \tilde{\imath}$

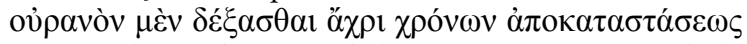
$\pi \alpha ́ v \tau \omega v]$ hasta el tiempo de la restauración universal, de que Dios habló por boca de sus santos profetas. (Hchs 3 19-26). Y en contraste: «Sepa, pues, con certeza toda la casa de Israel que Dios ha constituido Señor y Cristo a este Jesús a quien vosotros habéis crucificado». (Hchs 2, 36). Obsérvese cómo la primera cita manifiesta una cristología más primitiva: Jesús, resucitado o ascendido, está predestinado a manifestarse como el Cristo solo en la parousía. En cambio, en Hchs 2 36, Jesús ya ha sido designado Kyrios y Christos en su exaltación. De hecho, esta cristología helenista que acertamos a reconstruir tan someramente se halla en el fondo de la gran cristología paulina. Cristo no es solo un acontecimiento en la historia de Israel. Es una figura de estatura divina que rompe los estrechos moldes étnicos en los que permanecía el Mesías tradicional (cf. Flps 2, 5-8; Gal 3, 27-28). En cualquier caso, y en la cuestión que aquí planteamos, no nos atrevemos a decantarnos por ninguna de las dos alternativas.

51 A este respecto, no se puede obviar el hecho de que, en Marcos, la filiación divina de Jesús no es un hecho vinculado a su propia concepción como en $\mathrm{Lu}$ cas. Es muy probable que esta acaeciera en el momento del bautismo, tal como indica que los cielos se rasgaran: «En cuanto salió del agua, vio que los cielos se ras-

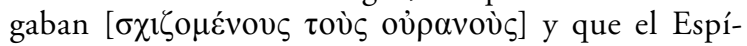

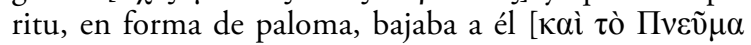

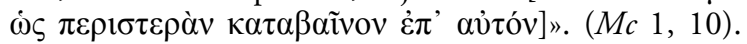
El Evangelio de los Ebionitas subraya la idea, menos clara en los canónicos, y recalca: «...y vio al Espíritu Santo en forma de paloma que bajaba y penetraba en

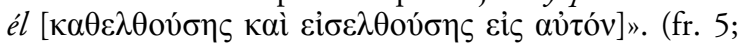
asimismo, EvHebr fr. 28, algo menos explícito: «... descendit fons omnis Spiritus Sancti et requievit super eum». [Hier. Comm. IV in Is. 11, 2]) (trad. A. Santos). El prodigio cósmico es, evidentemente, una forma de expresar la irrupción de la divinidad sobre la figura del profeta Jesús. De igual modo, resulta muy significativa la aparición del mismo verbo $\sigma \chi i \zeta \omega$ a la hora de describir los prodigios acaecidos a la muerte de Je-

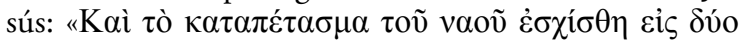

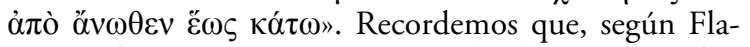
vio Josefo (BJ V 212-214), se trataba de una magnífica pieza textil de 55 codos $(24 \mathrm{~m})$ que representaba precisamente una imagen del cielo en hilos azul, escarlata, púrpura y lino blanco fino. Dicho sea de paso, la idea de que la divinidad había descendido sobre Jesús, en principio un simple mortal de virtudes eminentes, en el momento del bautismo ya se halla también presente en las cristologías gnósticas, empezando por la de Cerinto: «Iesum autem subiecit non ex virgine natum (...); fuisse autem Ioseph et Mariae filium (...). Et post baptismum descendisse in eum, ab ea principalitate quae est super omnia, Christum figura columbae». (Iren. Adv. Haer. I $26,1)$.

${ }_{52}$ Así, se ve en la polémica de Orígenes con $\mathrm{He}$ ráclides. Este distinguía en Cristo el cuerpo, el alma y el espíritu (diferente del Espíritu divino): «Los tres se separaron en el momento de la pasión y se juntaron en el momento de la resurrección. Se separaron en la pasión: ¿Cómo? El cuerpo (bajó) al sepulcro, el alma (fue) al Hades y el espíritu lo entregó al Padre». (Orig. Dial. Her. 7: SC 67, 70, 11. 17-19). En cambio, Orígenes habla de la asunción de cuerpo, alma y espíritu por Cristo para salvar al hombre integral. De hecho, este argumento también es esgrimido en la controversia antiapolinarista que se evidencia en Tertuliano. Una amplia discusión sobre la cuestión, en Grillmeier (1997, 308-309). 
La doctrina del gemelo místico, del alter ego espiritual ( $\sigma u ́ \zeta v \gamma o \varsigma)$, del hombre espejo que nos devuelve nuestra verdadera imagen, y que, como genio tutelar, representa la trascendencia de nuestro yo, entrará unos años después de redactados los Hechos de Tomás (...), en el corazón del pensamiento de Mani con la figura del «ángel guardián», del «consejero», del «doble celeste» (alTom = el gemelo), que en los momentos decisivos se revelaba al profeta babilonio. (Gómez de Liaño, 1998, II 42) $)^{53}$

Por otra parte, es muy digno de tener en cuenta el hecho de que la realidad espiritual y superior de Jesús — esto es, Cristo - se exprese a través de una figura que evoca la plena juventud vital, inmune al paso del tiempo y a la decrepitud. ${ }^{54}$ Tal motivo, ausente de los canónicos ${ }^{55}$-recordemos

53 Si bien la opinión tradicional veía a Mani (216277), el profeta maniqueo, en relación con el zoroastrismo, actualmente se tiende a enfatizar las deudas que mantiene con el judeocristianismo y el gnosticismo cristiano a través de sus vínculos con los elcasaítas, grupo de matriz ebionita. Cf. Eliade y Couliano (1997, 172). De hecho, el cristianismo arameo identificaba al Espíritu Santo con un ángel guardián personal, lo cual es indicio de lo primitivo de esta cristología - pensemos en las categorías angélicas de la cristología paulina—; y de que, en última instancia, se halla en la base de la doctrina maniquea. Por otra parte, la doctrina también se insinúa en el Himno de la Perla de los Hechos de Tomás (9, 108-113), siglo III. Un examen general de la cuestión, en Fauth 1986.

${ }^{54} \mathrm{La}$ cuestión de las diversas apariencias que adquiría el Resucitado ya fue objeto de amplia atención por parte de Orígenes (Cels. II 61-64). Sin duda, el caso más interesante de esta polimorfía es la del Cristo-Mujer, forjada, a fines del siglo II, por Priscila —o quizás Quintila—, una de las profetisas montanistas: «Y cuentan que en Pepuza una de ellas tuvo un sueño y vio a Cristo avanzar hacia ella de esta guisa, tal como dijo aquella perdida: 'En forma de mujer, ataviado con una estola resplandeciente, vino Cristo hacia mí, derramó en mí la sabiduría y me reveló que precisamente ese lugar era santo y que allí descendería desde el cielo la Jerusalén celeste’." (Epifanio Haer. 49.1) (Trad. G. Fontana). Lo que para la profetisa y sus castísimos seguidores, los montanistas, era acaso una visión sublime - un Cristo que ya había superado las ataduras físicas de la carne y la diferenciación sexual (cf. EvAegypt fr. 5) -, constituía, sin duda, para los obispos de Asia, hombres de orden y poder, una bofetada mayúscula que, en última instancia, ponía en entredicho su propia concepción de la jerarquía y el buen orden en el mundo.

55 No obstante, puede que algún pasaje de Marcos sea un eco de este motivo: «Yo os aseguro: el que no reciba el Reino de Dios como niño, no entrará en él». ( $M c$ 10, 15). De igual manera, hay algún pasaje lucano en el que también se insinúa algo de esta doctrina: «Jesús les dijo: 'Los hijos de este mundo toman mujer o marido; pero los que alcancen a ser dignos de tener parte en aquel mundo y en la resurrección de entre los muertos, ni ellos tomarán mujer ni ellas marido, ni pueden ya morir, porque son como ángeles'.» (Lc 20, 34-36). De un lado, la incapacidad de procrear y de acceder al matrimonio evoca un estado infantil; $y$, de otro, no podemos olvidar la tendencia de la literatura judía tardía a representar a los ángeles como jóvenes. Bástenos recordar el ejemplo del ángel que hace camino con Tobías: «Salió Tobías a buscar un hombre que conociera la ruta y fuera con él a Media. En saliendo, encontró a Rafael, el ángel, parado ante él; pero no sabía que era un ángel de Dios. Díjole, pues: ‘¿De dónde eres, joven?’ Le respondió: 'De los israelitas, tus hermanos y ando en busca de trabajo'. (...) Tobías le dijo: 'Espérame, joven, que voy a decírselo a mi padre...'.» (Tob 5, 4-7). La traducción de la Biblia de Jerusalén que aquí seguimos, al igual que la Vulgata («bone iuvenis») ofrecen el término «joven», en pos de un texto muy afín al Sinaiticus. En cambio, el texto de los Setenta, más cercano al Alexandrinus, omite tal caracterización. En cualquier caso, en los evangelios canónicos, las apariciones de Jesús nunca describen a un niño o a un jovencito. Es cierto, que muchas veces los discípulos son incapaces de reconocerlo, pero nunca se alude a una figura infantil o juvenil. Otra cosa es lo que ocurre en determinados relatos transmitidos por los apócrifos, en los que la polimorfía de Jesús ya se manifiesta en el propio período «biográfico»: "Al oírlo, [-relata Juan-] mi hermano dijo: 'Juan, ¿qué desea ese muchacho [ $\pi \alpha 1 \delta i ́ o v]$ que nos llama desde la orilla?' Yo respondí: ‘¿Qué muchacho?' Él, a su vez, dijo: 'Ese que me hace señales'. Respondí: 'Por las muchas horas de insomnio que hemos padecido en el mar estás viendo una visión, hermano mío, Santiago: ¿No ves a un varón de buena presencia, de pie, hermoso y de rostro alegre?' Volvió a decir: 'No lo veo, hermano. Pero desembarquemos y veamos qué quiere'.// Así, tras haber conducido la nave a tierra, observamos cómo él nos ayudaba a aferrar el barco a las amarras. Cuando nos alejamos de aquel lugar con la intención de seguirle, se me apareció de nuevo casi calvo, pero con una barba amplia y espesa, mas a Santiago (se mostró) como un jo-

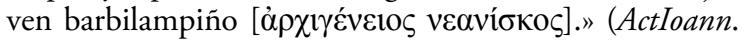
88-89; cf. Mt 4, 21-22) (trad. Pińero; del Cerro). 
las heridas y llagas que Tomás puede tocar en Juan (20, 24-29)—, cobró mayor auge, en cambio, entre los gnósticos:

Sus discípulos dijeron: ‘¿Qué día te revelarás a nosotros y qué día te veremos?’ Dijo Jesús: 'Cuando os desnudéis y no os avergoncéis y toméis vuestros vestidos y los pongáis bajo vuestros pies como niños pequeños y los pisoteéis, entonces veréis al Hijo del Viviente y no temeréis'. $(\text { EvTom. 37) })^{56}$

Y [se dirigió a él], diciendo: ‘¿Qué camino [tomaré] para subir a [Jerusalén]?’ El niño [contestó diciendo]: 'Di tu nombre, a fin de que te [muestre] el camino. Sabía [quién era Pablo]. Quiso mostrarse afable con él por medio de sus palabras a fin de hallar excusa para conversar con él. El niño tomó la palabra y dijo: Sé quién eres, Pablo, que tú eres el que fue bendecido desde el vientre de su madre. Ahora bien, yo [he venido] a ti a fin de que [subas a Jerusalén] hacia tus colegas [apóstoles]. Por esto [has sido llamado]. Yo soy [el Espíritu que hace camino] contigo'. (Apoc. Pauli 18)

En definitiva, algunas de las versiones más antiguas del cristianismo contaron en su arsenal teológico con un Jesús "desdoblado", del que solo quedarían estos restos narrativos del segundo evangelio; $y$, por supuesto, en la tradición gnóstica, en la que prevaleció exclusivamente el «gemelo espiritual», apuesta que, de paso, anulaba cualquier atisbo de carnalidad en Jesús: ${ }^{57}$

Muchos seductores han salido al mundo, que no confiesan que Jesucristo ha venido en carne. Ese es el Seductor y el Anticristo. (2Jn 7)

En rigor, esta identificación entre el muchacho del prendimiento y el de la tumba vacía debió de perderse muy pronto. ${ }^{58}$ No solo no se halla ninguna referencia a ella en los autores cristia-

56 En rigor, el simbolismo no es exclusivamente gnóstico, ni mucho menos: «Por lo demás, después de su resurrección se hallaba Jesús en una especie de estado fronterizo entre la solidez del cuerpo antes de la pasión

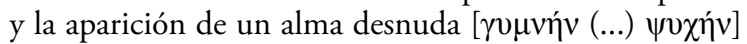
del cuerpo». (Orig. Cels. II 61).

57 A este respecto, es posible que la alusión joánica a

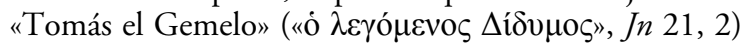
sea un mínimo rastro de la existencia de ese personaje, abolido en la ortodoxia. En cualquier caso, deseamos subrayar que nuestra hipótesis no pasa, en ningún caso, por ver en Marcos ningún componente gnóstico, ni siquiera pregnóstico. Nos hallaríamos, simplemente, ante una cristología muy primitiva conformada con arreglo a la reflexión judía de su tiempo. Otra cosa es que muchos de sus elementos pasaran, en fases históricas posteriores, al utillaje mental del gnosticismo, de cuyos textos nos servimos en la medida en que carecemos de otras fuentes más cercanas en el tiempo.

58 De hecho, no es inverosímil que, a pesar de la fecha temprana de su trabajo (ca. 70-75), el autor de Marcos ya hubiera perdido algunas de las claves explicativas de muchos de los relatos que incorporó a su obra. Tal es el caso de la doble multiplicación de los panes y los peces $(M c$ 6, 32-44; 8, 1-21): «Ellos hablaban entre sí que no tenían panes. Dándose cuenta, les dice: '¿Por qué estáis hablando de que no tenéis panes? ¿Aún no comprendéis ni entendéis? ¿Es que tenéis la mente embotada? (...) ¿No os acordáis de cuando partí los cinco panes para los 5.000? ¿Cuántos canastos llenos de trozos recogisteis?' 'Doce', le dicen. 'Y cuando partí los siete entre los 4.000, ¿̇cuántas espuertas llenas de trozos recogisteis?' Le dicen: 'Siete.' Y continuó: ‘¿Aún no entendéis?" ( $M c$ 8, 16-21). Como se ve, la respuesta del Jesús marcano resulta de lo más elusiva. Hasta el punto de que el significado del prodigio solo se puede reconstruir desde la exégesis. Dejando a un lado su eventual -y tardía - interpretación sacramental ( $c f . J n$ 6), ambos episodios responden a una ficción taumatúrgica en la que la ubérrima utopía del Reino se hace manifiesta a través de la abundancia de la que participa la hambrienta multitud. Y en la medida en que el relato no es sino una proyección de la experiencia comunitaria, su significado es claro, al menos a nuestro juicio: el grupo cristiano, heredero de la promesa mesiánica, materializa en sí la inagotable munificencia del Reino de Dios y subviene a las necesidades de todos sus miembros. La prolongación en el tiempo de la promesa originaria se evidencia en el número de canastos de pan que sobran del doble banquete, doce y siete respectivamente, los 
nos de la Antigüedad; lo más significativo es que las versiones latinas antiguas traducen el término

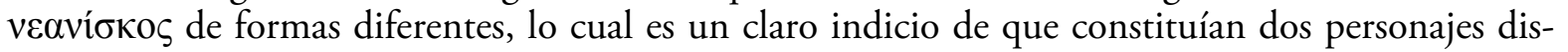
tintos para sus autores:

Adulescens autem quidam sequebatur illos amictus sindone nuditatis... (Cod. Bez.)

Et intrantes in monumentum viderunt iuvenem sedentem ad dexteram. (Cod. Bez.)

Adolescens autem quidam sequebatur eum amictus sindone super nudo... (Vulgata)

Et introëuntes in monumentum viderunt iuvenem sedentem in dextris. (Vulgata)

Mas volvamos al Marcos canónico. A nuestro juicio, y somos conscientes de que nos servimos de un argumento ex silentio, una de las posibles razones por las que sus párrafos finales fueron cercenados puede deberse, precisamente, al hecho de que quizás en él hubiera alguna manifestación o

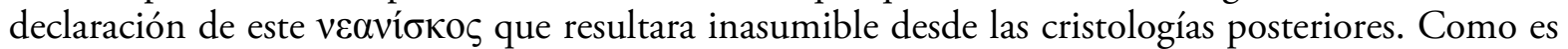
sabido, los manuscritos antiguos de Marcos acaban abruptamente con la frase «... y [las mujeres] no dijeron nada a nadie porque tenían miedo». $(M c 16,8) .{ }^{59}$ Posteriormente, hubo varios intentos de substituir el final desaparecido - ¿o acaso suprimido? - con noticias seguramente menos novedosas. De entre estos intentos cabe destacar, por supuesto, el final que conforma hoy la versión estándar $(M c 16,9-20)$, y que no es sino un refrito de noticias procedentes del texto de Lucas. ${ }^{60}$

cuales simbolizarían precisamente los grupos dirigentes de cada una de las comunidades cristianas más antiguas: los Doce y los Siete, ministros todos en la mesa del banquete mesiánico establecido en la Jerusalén recreada en la obra del autor lucano (Hchs 6, 1-7; asimismo, 2, 44-46; 4, 32-37). En rigor, esta interpretación del sentido de estos pasajes es personal y no viene avalada por los comentarios más prestigiosos del evangelio. Así, Gnilka $(2005,305)$ apunta: «No existe una base suficientemente firme para interpretar simbólicamente los números». Y más tajante se muestra páginas después: «Bastantes querrían valorar los siete panes - como los siete cestos en 8- como expresión simbólica del colegio de los siete de la comunidad helenística (Hchs 6, 3). Pero esto es sumamente cuestionable desde el punto de la historia de la tradición” $(2005,353)$. Sin embargo, a nuestro juicio, la interpretación que hemos dado a la cantidad de cestos sobrantes es perfectamente asumible, sobre todo, porque el comentarista no explica las dificultades para asumir tal interpretación. Por su parte, Heising $(1927,54)$ interpretó los doce cestos como una referencia a los Doce apóstoles y los cinco panes como símbolo del Pentateuco. Por su parte, el comentario de Marcus (2011, 487-490) abunda en la interpretación mosaica de las cifras del pasaje, sin interpretar tampoco los números de cestos sobrantes. De igual manera, tampoco acepta una interpretación ni de lejos semejante a la nuestra para el número siete: «... algunos piensan que esos números dan a entender que la multitud estaba integrada por gentiles; pero resulta dudoso que eso pueda deducirse con seguridad del simbolismo del número siete y del cuatro mil. (...) El más importante de esos números es el siete, como manifiesta el hecho de que aparezca tres veces aquí $(8,5.6 .8)$ y de nuevo en $8,20$. Pero el número siete no aparece especialmente asociado a los gentiles, ni en las fuentes judías ni en Marcos. Si en nuestro pasaje tiene alguna asociación especial, será con la noción de plenitud escatológica y de la identificación de Jesús como figura mosaica.» (2011: 583).

59 Un examen general del problema del final de Marcos, en Smith (1995, 209-31).

60 Posteriormente, un desconocido editor añadió doce versículos $(M c 16,9-20)$ que resumen la versión lucana del relato de la resurrección. El origen lucano del apéndice de Marcos es indiscutible, ya que incorpora en su breve narración elementos que solo se hallan presentes en Lucas. Sin entrar en pormenores: la Magdalena es la mujer de la que Jesús ha expulsado siete demonios $(L c 8,2)$; Jesús se aparece a dos discípulos que van camino de una aldea (Emaús) (Lc 24, 13-35); Jesús es elevado al cielo $(L c 24,51)$. A ello habría que añadir la extraña profecía que asegura a los discípulos que no morirán aunque les muerdan las serpientes, motivo que parece desarrollar la anécdota lucana de Pablo mordido por una de ellas en Malta (Hchs 28, 3-6). No obstante, en algunas versiones latinas del texto marcano todavía se puede vislumbrar la presencia de nuestro personaje: «Omnia autem quaecumque praecepta erant et qui cum puero erant breviter exposuerunt. Posthaec et ipse Ihesus adparuit, et ab orientem usque usque in orientem [sic (=ab orientem usque ad occasum)] misit per illos sanctam et incorruptam [add. praedicationis (?) marg.] salutis aeternae. Amen.» (Codex Bobbiensis [siglos IV-v]). Un análisis de la cuestión, en Haelewyck (1999, 27-52). 
En cualquier caso, la figura alegórico-religiosa había perdido su condición originaria y quedó transformada en un misterioso e incongruente personaje cuya presencia en la escena del prendimiento resultaba incomprensible. $Y$ es que ni la más fértil de las imaginaciones acertaría a formular una conjetura verosímil que explicara qué hacía un muchacho desnudo y cubierto con una mortaja

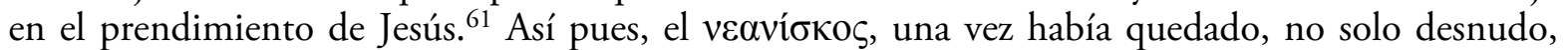
sino narrativamente aislado (pues la reformulación angélica ya impedía cualquier identificación con el individuo de la tumba vacía), dio lugar a varios desarrollos en diversos episodios evangélicos de otras tradiciones cristianas:

Dominus autem cum dedisset sindonem servo sacerdotis, ivit ad Iacobum... (EvHebr apud Hier. De vir. ill. 2)

Obsérvese cómo, en este relato, la aparición de Jesús se produce a su hermano Santiago, el héroe judeo-cristiano por excelencia, no a Pedro ( $c f$. 1Cor 15, 5). Con todo, lo más significativo es

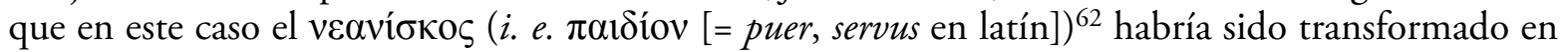
el criado del ignoto sacerdote que habría recibido la mortaja de Jesús. Más aún, ¿no nos hallaremos ante el mismo personaje mencionado en $M c 14,47$, aquel siervo del sumo sacerdote que perdió la oreja herido por un golpe de espada? ${ }^{63}$ La desesperante falta de contexto de la cita nos impide tratar siquiera de aventurar una conjetura que explique el sentido del curioso pasaje. Con todo, no deja ser significativo que aparezcan juntos dos elementos presentes en la escena del prendimiento marcano: la mortaja de Jesús y el siervo del sacerdote.

Y lo que es más, esta pérdida del auténtico significado de la figura dio lugar a curiosas corrupciones en los manuscritos de Marcos. Como es lógico, hasta ahora nos hemos venido sirviendo del texto alejandrino, el que conforma la base del moderno texto crítico de Marcos. Sin embargo, no podemos perder de vista que, durante muchos siglos, los cristianos contemplaron la escena de forma algo distinta a la que lo hacemos nosotros:

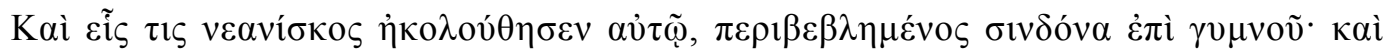

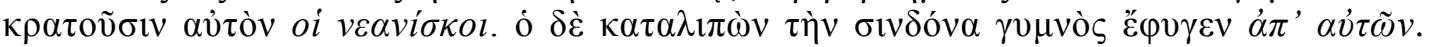
$(M c 51-52)^{64}$

61 De hecho, la propia narración ya debía de resultar bastante incómoda para los cristianos de la ortodoxia.

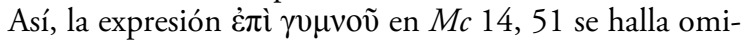
tida en varios manuscritos importantes: $W$ (Washingtonianus, siglo v) y $X$ (Monacensis, siglo $\mathrm{x}$ ). Las razones de tal omisión son obvias: una alusión directa a la desnudez de un discípulo de Jesús resultaba ofensiva para los piadosos copistas del texto y también para sus lectores. Un análisis de la cuestión, en Brown (1994, 295). En contraste, $0, p$, y 565 presentan una variante con el nominativo $\gamma u \mu v o ́ \varsigma$, que, dicho sea de paso, resultaba muy del gusto de M. Smith (1982, 458, n. 19).

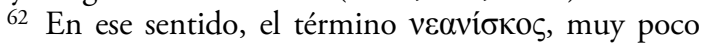
frecuente en el griego bíblico, aparece con el significado de «joven» en Gen 19, 4 y de servidor en Jue 19, 19. Por otra parte, en el Nuevo Testamento, y dejando a un lado los pasajes ya citados, aparece en las siguientes ocasiones:

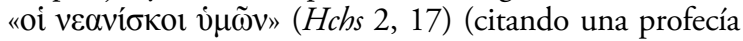

de Joel $[3,1]$, aunque la versión de los Setenta solo dice:

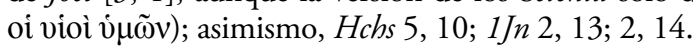

63 «Uno de los presentes, sacando la espada, hirió al

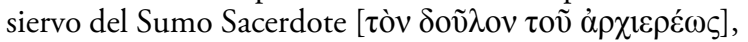
y le llevó la oreja». (Mc 14, 47; $M t$ 26, 51; Lc 22, 50). Juan da más detalles del acontecimiento y de su figura: «Entonces Simón Pedro, que llevaba una espada, la sacó

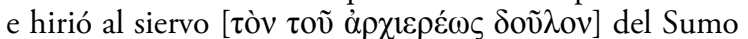
Sacerdote, y le cortó la oreja derecha. El siervo se llamaba Malco». (Jn 18, 10). Por su parte, Gnilka (2005, II 316) considera que el individuo herido era el jefe de la tropa que acudió a prender a Jesús.

64 Se trata del textus receptus que todavía se acepta en la editio Elzeviriana (1624) e incluso en la de Griesbach (1806). Por su parte, el texto del Codex Bezae (siglo v)

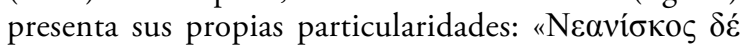

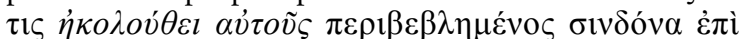

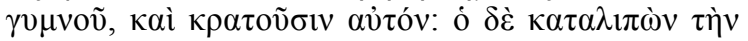


Obsérvese que algún copista tardoantiguo (el que está detrás del grupo de códices bizantinos en minúscula que dieron lugar al textus receptus, que, a su vez, fue el sancionado por las ediciones de Erasmo y Estienne), resuelto a aclarar el problema del misterioso discípulo desnudo, decidió incluirlo en un inverosímil tropel de muchachos que, al parecer, andarían mezclados con

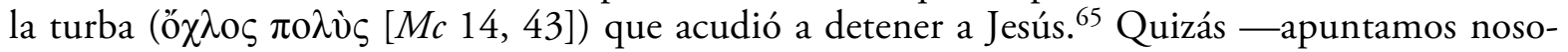
tros- los quiso identificar con el grupo de niños $(\pi \alpha \tilde{i} \delta \varepsilon \varsigma)$ de Mateo $(22,15-16)$ que aclaman a Jesús tras su violenta entrada en el Templo. Con todo, lo que no logró explicar es por qué razón andaba él tan ligero de ropa con el relente que, es de suponer, hacía aquella noche del $13 \mathrm{de} \mathrm{Ni}$ sán (cf. Jn 18, 18).

Cerramos, pues, nuestro trabajo reiterando que, al menos a nuestro juicio, hemos realizado una argumentación fundada y convincente, o al menos verosímil, de nuestra hipótesis: el muchacho desnudo de Marcos fue una creación narrativa de la primitiva tradición cristiana como una figura de carácter simbólico que daba cuenta de la realidad crística de Jesús, quien iba a hurtarse a la muerte. Sus captores solo se habrían quedado con un cuerpo cuyo trasunto era la mortaja con la que envolvía su desnudez. Tras ser sepultado, ese mismo individuo se manifestará revestido ya de la resplandeciente túnica que indica su plena glorificación mesiánica.

No obstante, también somos conscientes de la dificultad que siempre entraña la exégesis simbólica del cualquier texto. Las propuestas de corte histórico son evaluables con arreglos a criterios más seguros, en particular porque su eventual fortaleza estriba en que resultan contrastables, al menos en términos de verosimilitud, con el conjunto de realidades conocidas de una época dada. En cambio, una hipótesis como la nuestra se articula, ya de entrada, con arreglo a una perspectiva «ecuacional», en la que se trata de despejar una incógnita que, por definición, jamás se hace explícita en el propio texto, como exige la propia naturaleza del símbolo. De ahí la imposibilidad de afirmar con rotundidad la validez de este tipo de propuestas. Con todo, el conjunto de argumentos que hemos ofrecido en estas páginas nos persuaden de que el lector puede considerar convincente nuestra hipótesis. Sobre todo, porque se ajusta al horizonte de creación de los textos neotestamentarios.

Y es que nuestro análisis revela, una vez más, que, a poco que se profundice en su lectura, la aparente sencillez de los evangelios se desvanece por completo. Sus autores se movían en un paradigma cultural ajeno por completo a las claves retórico-poéticas en las que se desenvolvían sus contemporáneos del mundo clásico. Pero eso no hacía de ellos autores cándidos o poco sutiles: el no tener un griego singularmente pulido no hace de ellos individuos irreflexivos o poco conscientes del peso ideológico de sus obras. Su mundo es el de la exégesis veterotestamentaria y sus textos están construidos sobre un entramado de alusiones y ecos bíblicos y teológicos extraordinariamente complejos y sutiles, surgidos de una tradición religiosa muy antigua y de una densa reflexión secu-

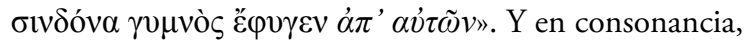
su versión latina reza: "Adulescens autem quidam sequebatur illos amictus sindone nuditatis et tenuerunt illum. At ille relicta sindone profugit nudus ab eis». En este caso, el copista apuesta por una lectio facilior y presenta al joven siguiendo, no a Jesús, sino a sus captores o quizás a sus discípulos ( $c f . M c 14,50)$. En cambio, la $V u l-$ gata se halla más cerca de la versión estándar del texto. «Adolescens autem quidam sequebatur eum amictus sindone super nudo: et tenuerunt eum. At ille reiecta sindone, nudus profugit ab eis». Finalmente, conclui- mos la nota señalando que las versiones siríaca, arábica, pérsica y etiópica prescinden de la expresión "de ellos»

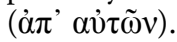

65 Barnes considera que se trata de los soldados romanos que habrían acudido a prender a Jesús: "The young men: The Roman soldiers: They were called 'young men' because they were made up chiefly of youth. This was a Jewish mode of speaking. See Genesis 14:24; 2 Samuel 2:14; Isaiah 13:18». (Albert Barnes' Notes on the Whole Bible. En: http://www.studylight.org/commentaries/ $\mathrm{bnb} /$ view.cgi? bk=40\&ch=14. [Online]). 
lar, lo que les permite trenzar, releer y crear todo un mundo de alusiones y motivos, que, si bien podían resultar transparentes en sus ambientes comunitarios concretos, en nuestros días, solo somos capaces de reconstruir a través de una denodada labor exegética, siempre sometida al tanteo y la incertidumbre.

\section{Bibliografía Citada}

\subsection{Fuentes}

Alfonso Díaz, J. y Vargas Machuca, A., 1996, Sinopsis de los Evangelios, Madrid: Universidad Pontificia de Salamanca.

BEDA, 1563, Expositio in Evangelium secundum Marcum, Basel: Ioannes Hervagius.

Clemente de Roma, 1994, Carta a los Corintios; Homilia anónima (Secunda Clementis), Madrid: Ciudad Nueva. Ed. y trad. al español de J. J. Ayán Calvo.

Edo, P. M. (ed.), 2015, El evangelio de Pedro, Salamanca: Sígueme.

Epifanio de Salamina, 1915-1922, Ancoratus und Panárion, vol. 1 y 2, (ed. de Karl Holl), Leipzig: Hinrichs; vol. 3 (ed. de Hans Lietzmann), Leipzig: Hinrichs, 1933.

Eusebio de Cesarea, 2002, Historia eclesiástica, Madrid: BAC. Ed. y trad. esp. de A. Velasco-Delgado.

Evangelio de Tomás: en Trevijano, R., 1997, Estudios sobre el Evangelio de Tomás, Madrid: Ciudad Nueva.

Filón de Alejandría, 2010, Las insidias de lo peor contra lo mejor, en: J. P. Martín (ed.), Filón de Alejandria: obras completas II, Madrid: Trotta. Trad. esp. de M. Coria.

Ireneo de Lyon, 1857, Adversus Haereses, Patrología Graeca (Migne VII), Paris: Imprimerie Catholique.

—, 1983, en Los gnósticos, Madrid: Gredos, dos vols. Trad. esp. de J. Montserrat Torrents.

Nestle, E., Nestle, E. y Aland, K. (eds.), 1975 (26a ed.), Novum Testamentum Graece, Stuttgart: Deutsche Bibelgesellschaft.

Nueva Biblia de Jerusalén, 1998, Bilbao: Desclée de Brower.

Orígenes, 2001, Contra Celso, Madrid: BAC. Trad. esp. de D. Ruiz Bueno.

Piñero, A., 2000, Segundo tratado del Gran Set, en: Textos gnósticos. Biblioteca de Nag Hammadi, III, Madrid: Trotta.

Piñero, A., y G. Del Cerro, G. del, 2004, Hechos apócrifos de los apóstoles, dos vols., Madrid: BAC.

Possinus, P., 1673, Catena Graecorum Patrum in Evangelium secundum Marcum, Roma: Michael Hercules.

Santos Otero, A., 1993, Los evangelios apócrifos, Madrid: BAC.

Swete, H. B., 1909-1922, The Old Testament in Greek according to the Septuagint, Cambridge University Press.

ТеоғILAсто, 1527, Theophylacti archiepiscopi Bulgariae in quatuor Evangelia enarrationes, denuo recognitae, Antwerp: J. Mazochius. (trad. lat. de Ecolampadio).

Tomás de Aquino, 1851, Catena aurea super quattuor Evangelistas, Avignon: Fr. Seguin.

\subsection{Estudios monográficos}

Barnes, A., Notes on the Whole Bible. En: http://www.studylight.org/commentaries/bnb/view. cgi?bk=40\&ch=14. [Online]).

Bauckham, R., 2007, Jesus and the eyewitnesses. The Gospels as eyewitness testimony, Grand Rapids: Eerdmans.

Benoit, P., Boismard, M. E. y Malillos, J. L., 1977, Sinopsis de los cuatro evangelios con paralelos de los apócrifos y de los padres, vol. II, Bilbao: Desclée de Brouwer. [orig. fr. 1972].

Brown, R. E., 1994, The death of the Messiah, vol. I, New York: Doubleday.

Brown, S. G., 2003, "On the Composition History of the Longer ('Secret') Gospel of Mark», Journal of Biblical Literature 122.1, 89-110. 
Brown, S. G., 2005, Mark's Other Gospel: Rethinking Morton's Smith Controversial Discovery, Wilfrid Laurier University Press.

Cranfield, C. E. B., 1959, The Gospel according to St Mark: An Introduction and Commentary, Cambridge Greek Testament Commentaries.

Crossan, J., 1974, «Empty tomb and absent Lord (Mark 16: 1-8)», en: W. Kelber (ed.), The Passion in Mark, Philadelphia: Fortress Press, 147-148.

De Moor, J. C., 1971, The seasonal pattern in the Ugaritic myth of Ba'lu, according to the version of Ilimilku, Alter Orient und Altes Testament, 16, Vluyn: Verlag Butzon \& Berker Kevelear.

De Villiers, P. G. R., 2010, "The powerful transformation of the young man in Mark 14:51-52 and 16:5», HTS Teologiese Studies/Theological Studies 66(1). En: http://www.hts.org.za/index.php/HTS/ article/view/893/1130 (Online).

Dibelius, M., 1949, Jesus, Philadelphia: Westminister Press. [orig. al. 1939]. En: http://media.sabda.org/ alkitab-2/Religion-Online.org\%20Books/Dibelius,\%20Martin\%20-\%20Jesus.pdf.

DodDs, E. R., 1986, Los griegos y lo irracional, Madrid: Alianza Editorial. [orig. ing. 1951].

Dormeyer, D., Galindo, F., 2007, Comentario a los Hechos de los apóstoles: Modelo de nueva evangelización, Estella: Verbo Divino.

Edwards, D., 1992, "Dress and Ornamentation», Anchor Bible Dictionary, 2.232-238.

Elliott, J. H., 2013, La Primera Carta de Pedro: Edición bilingüe y comentario, Salamanca: Sígueme. [orig. ing. 2000].

Eliade, M. y Couliano, I. P., 1997, Diccionario de las religiones, Barcelona: Círculo de Lectores [orig. fr. 1990].

Fauth, W., 1986, «Syzygos und Eikon. Manis himmlischer Doppelgänger vor dem Hintergrund der platonischen Urbild-Abbild-Theorie», Perspektiven der Philosophie. Neues Jahrbuch 12, 41-68.

Fontana Elboj, G., 2013, «La autoría del Evangelio de Lucas a la luz del fragmento 2 Lightfoot de Papías de Hierápolis», en: J. A. Beltrán, A. Encuentra, G. Fontana, A. Magallón, R. Marina (eds.), Otium cum dignitate, Zaragoza: Universidad de Zaragoza, 665-676.

-, (2014a), El Evangelio de Juan. La construcción de un texto complejo: orígenes históricos y proceso compositivo, Zaragoza: Prensas Universitarias de Zaragoza.

—, (2014b), "Christianos ad leonem: la génesis de un odio construido», en: A. Duplá, Ma Victoria Escribano, L. Sancho, Ma A. Villacampa (eds.), Miscelánea de estudios en homenaje a Guillermo Fatás Cabeza, Zaragoza: Institución Fernando el Católico, 313-322.

Fowler, M., 1998, "Identification of the Bethany Youth in the Secret Gospel of Mark with other Figures Found in Mark and John", Journal of Higher Criticism 5/1, 3-22.

Gnilka, J., 2005, El evangelio según san Marcos: Mc 8, 27-16, 20 (vol. II), Salamanca: Sígueme. [orig. al. 1979].

Gómez de Liaño, I., 1998, El círculo de la sabiduría: diagramas del conocimiento en el mitraísmo, el gnosticismo, el cristianismo y el maniqueismo, dos vols., Madrid: Siruela.

Gourgues, M., 1981, "A Propos du symbolisme christologique et baptismal de Marc 16.5», New Testament Studies 27, 672-678.

Grabbe, L. L., 1976, «The Seasonal Pattern and the 'Baal Cycle'», Ugarit-Forschungen 8, 57-63.

Grillmeier, A., 1997, Cristo en la tradición cristiana, Salamanca: Sígueme. [orig. al. 19903]

Haelewyck, J. C., 1999, «La version latine de Marc», Mélanges de science religieuse 56, 27-52.

Haren, M. J., 1998, "The Naked Young Man: a Historian’s Hypothesis on Mark 14, 51-52», Biblica 79, 525-531.

Heising, A., 1927, Die Botschaft der Brotvermehrung, Stuttgart: Katholisches Bibelwerk.

Henry, M., Commentary. En: https://www.biblegateway.com/resources/matthew-henry/Mark.14.43Mark.14.52. (Online).

Jackson, H. M., 1997, "Why the Youth Shed His Cloak and Fled Naked: The Meaning and Purpose of Mark 14:51-52», Journal of Biblical Literature 116 (2), 273-289.

Jeffery, P., 2007, The Secret Gospel of Mark Unveiled: Imagined Rituals of Sex, Death, and Madness in a Biblical Forgery, Yale University Press. 
Johnson, L.T., 1999, The writings of the New Testament: An interpretation, Minneapolis: Fortress Press.

Klostermann, E., 1950, Das Markusevangelium, Tübingen: Mohr.

Koester, H., 1983, «History and Development of Mark's Gospel (from Mark to Secret Mark and Canonical Mark)», en: B. Corley (ed.), A Time for Reappraisal and Fresh Approaches: Colloquy on New Testament Studies, Macon: Mercer University Press, 35-85.

Lane, W. L., 2002, The Gospel according to Mark, New International Commentary on the New Testament, Grand Rapids: Eerdmans.

Lohmeyer, E., 1937, Das Markus-Evangelium. Kritisch-exegetischer Kommentar über das Neue Testament, Götingen: Vandenhoeck \& Ruprecht.

Marcus, J., 2011, Marcos (Mc 8-16), Salamanca: Sígueme. [orig. ing. 2009]

McIndoe, J. H., 1969, «The Young Man at the Tomb», Expository Times 80, p. 125.

McVann, M., 1994, «Reading Mark Ritually: Honor-Shame and the Ritual of Baptism», en: M. McVann (ed.), Transformations, Passages, and Processes: Ritual Approaches to Biblical Text, Semeia, 67, 179-198.

Meuli, K., 1935, «Scythica», Hermes 70, 121-176.

Moloney, F. J., 2002, The Gospel of Mark: A Commentary, Peabody: Hendrickson. En: http://www. wtsbooks.com/common/pdf_links/9780801048418.pdf. (Online)

Myllyкоsкi, M., 2002, «What happened to the body of Jesus?», en: H. I. Räisänen et al. (eds.), Fair play: Diversity and conflicts in early Christianity: Essays in honour Heikie Räisänen, Leiden: Brill, 43-82.

Neirynck, F., 1979, "La fuite du jeune homme nu en Mc 14,51-52», Ephemerides Theologicae Lovanienses $55,43-66$.

Pesch, R., 1977, Das Markusevangelium. Teil 2: Kommentar zu Kap. 8,27-16,20, Freiburg im Breisgau: Herder.

Rius-Camps, J., 2008, El Evangelio de Marcos: etapas de su redacción: redacción jerosolimitana, refundición a partir de Chipre, redacción final en Roma o Alejandría, Estella: Verbo Divino.

Robinson, J. A. T., 1962, "The most primitive christology of all?», en J. Robinson (ed.), Twelve New Testament Studies, Naperville: Alec R. Allenson, 139-153.

Schenk, W., 1974, Der Passionsbericht nach Markus. Untersuchungen zur Überlieferungsgeschichte der Passionstraditionen, Gütersloh: Gerd Mohn.

Scroggs, R., Groff, K. I., 1973, «Baptism in Mark: Dying and Rising with Christ», Journal of Biblical Literature $92.4,531-548$.

Sмiтh, M., 1973, Clement of Alexandria and a Secret Gospel of Mark, Harvard University Press.

—, 1982, Clement of Alexandria and Secret Mark: the Scocre and the End of the first Decade, Harvard University Press.

Smith, St. H., 1995, A Divine Tragedy: Some Observations on the Dramatic Structure of Mark's Gospel, Leiden: Brill.

Talley, T. J., 1982, «The Origin of Lent at Alexandria», Studia Patristica 18, 594-612.

TAte, W. R., 1995, Reading Mark from the Outside: Eco and Iser Leave Their Marks, San Francisco: International Scholars Publications.

Theissen, G., 1999, The Gospels in Context: Social and Political History in the Synoptic Tradition, Edimburg: T. \& T. Clark Publishers. [orig. al. 1989].

Thorday, A., 2005, "The role of the Neaniskos in the Easter Mystery according to Mark», Sacra Scripta. Journal of the Center for Biblical Studies 1-2, 63-72.

VANHOYe, A., 1971, «La fuite du jeune homme nu (Mc 14, 51-52)», Biblica 52, 401-406.

Waetjen, H., 1968, "The ending of Mark and the Gospel's shift in eschatology», Annual of the Swedish Theological Institute 4, 116-120.

YARNOLD, E., 1972, The awe-inspiring rites of initiation: baptismal homilies of the fourth century, Slough: St. Paul Publications.

ZAHN, Th., 1899, Einleitung in das Neue Testament, vol. II, Leipzig: Deichert. 